\title{
Okul Öncesi Öğretmenlerinin Sınıf İçi Etkileşim Örüntülerinin İncelenmesi: Sınıf Söylemi Analizi Yaklaşımı*
}

\section{Investigating Preschool Teachers' In-Class Patterns of Interactions: Classroom Discourse Analysis Approach ${ }^{*}$}

\author{
Serenay BAŞALEV ${ }^{a}$, Yılmaz SOYSAL ${ }^{b}$
}

\section{Öz}

Bu çalıșma iki okul öncesi öğretmeninin sınıf içi öğretimlerinde ortaya çıkan etkileșim örüntülerinin incelenmesini amaçlamaktadır. Durum çalıșması olarak tasarlanan bu araștırmanın katııımclarını iki okul öncesi öğretmeni ve 52 okul öncesi öğrencisidir. Çalışmanın veri setini sınıf içi uygulamaların video kayıtları ( $n$ = 17. 302 dakika) olușturmaktadır. Oğretmenlerin söylemleri sosyokültürel söylem analizinin bir kolu olan sistematik gözlem yöntemi ile analiz edilmiştir. Sistematik gözlemlerde analiz birimi öğretmenlerin cümleleridir. Her bir öğretmen cümlesi hem teori hem de veri temelli olarak bu çalışma kapsamında geliștirilen Üclü Etkileșim Öüntüsü Kodlama Kataloğu aracılı̆ı ile kodlanmıștır. Ögretmenlerin üc farkl tipte etkileşim örüntüsünü farklı frekanslarla sergilediği görülmüștür: Başlat-Cevapla-Değerlendir (BCD), Bașlat-Cevapla-Açıkla (BCA) ve Başlat-Cevapla-Takip Sorusu (BCT). Öğretmenlerin sıklıkla takip sorularını kullandığı (BCT) ve aynı zamanda sınıf söyleminde olgu ve durumları açıklayıcı (BCA) ya da öğrenci ifadelerini değerlendirici (BCD) söylemler sergilediği de belirlenmiștir. Ek olarak, öğretmenlerin diyaloglar esnasında hangi tür konusma ikilisini; T-S (öğretmen-öğrenci) ve/veya S-S (öğrenci-öğrenci), tercih ettiğ belirlenmiștir. Her iki öğretmenin de sınıf söylemine yoğun müdahalelerinin olduğu ve öğrenci - öğrenci arasında yaşanan diyalogların kısıtlı olduğu görülmüştür. Elde edilen bulgular doğrultusunda öğretmen farkındalığı bağlamında önerilerde bulunulmuștur.

Anahtar Kelimeler: Etkileșim Örüntüsü, Okul Öncesi Eğitimi, Sistematik Gözlem, Söylem Analizi

\begin{abstract}
This study purposed to examine the patterns of interactions of two preschool teachers emerged during their in-class teaching. The participants of this study, which was designed as a case study (naturalistic inquiry), were two preschool teachers and 52 pupils. The data set of the present study included videobased records of the in-class implementations ( $n=17,302$ minutes). Teachers' discourses (e.g. articulations, externalisations) were analysed through the systematic observation approach that is a branch of sociocultural discourse analysis. In systematic observations, the unit of analysis was the analytical utterances (sentences) of the teachers. Each teacher-led verbalisation was coded through the Triadic Pattern of Interaction Coding Catalogue that was developed within the frame of the current study by a both data-driven theory-laden manner. The teachers displayed three different typologies of the pattern of interaction with different frequencies: Initiate-Response-Evaluate (IRE); Initiate-Response-Explicate (IREX); Initiate-Response-Follow-up questioning (IRF). The IRF triadic was mostly enacted by the teachers in addition to the IREx triadic that was staged in order to explicate/elicit the cases and phenomena under consideration and the IRE triadic that was displayed for assessing the student-led utterances. Furthermore, it was detected that which typologies of the talk dyads, e.g.. T-S (teacher-student) and/or S-S (student-student), were preferred by the teachers. The teachers had intensified interventions in the classroom talks and the dialogues between student-student were substantially restricted. In line with the deduced findings, suggestions were offered in the context of teacher noticing
\end{abstract}

Keywords: Discourse Analysis, Pattern Of Interaction, Preschool Education, Systematic Observation

\section{Makale Hakkında}

Tür: Araştırma

Geliş Tarihi: 25 Ekim 2020

Kabul Tarihi: 14 Aralık 2020

Yayın Tarihi: 16 Aralık 2020

DOI: $10.31805 /$ acjes.816264

Sorumlu Yazar:

Serenay BAȘALEV

istanbul Aydın Üniversitesi,

Istanbul/Türkiye.

E-posta: sbasalev@aydin.edu.tr

\section{About the Article}

Type: Research Received: 25 October 2020 Accepted: 14 December 2020 Published: 16 December 2020 DOI: 10.31805/acjes.816264Corresponding Author Serenay BAŞALEV İstanbul Aydın University İstanbul/Turkey E-mail: sbasalev@aydin.edu.tr

\section{Önerilen APA Atıf Biçimi / Suggested APA Citation}

Bașalev, S., \& Soysal, Y. (2020). Okul öncesi öğretmenlerinin sınıf içi etkileșim örüntülerinin incelenmesi: Sınıf söylemi analizi yaklașımı. Academy Journal of Educational Sciences, 4(2), 111-127. http://dx.doi.org/10.31805/acjes.816264 
Giriş

Öğretimsel faaliyetler sırasında öğretmenler çeşitli söylemsel roller sergilemektedir ve bu roller öğretmenin sözel ifadeleri, jestleri, tonlaması ve sınıf içindeki bedensel duruşu olarak görülebilir (Chin, 2006). Bilgi, öğretmen merkezli öğretimsel yaklaşımlarda öğretmen tarafından aktarılırken; öğrenci merkezli öğretimsel yaklașımlarda topluluk tarafından yapılandırılmaktadır (Chin, 2007, Edwards ve Mercer, 1987; Lemke, 1990). Buna paralel olarak öğretimsel faaliyetlerde bilgi hem öğretmen söylemleri aracılığıyla hem de öğrencilerin birbirleri arasında geliştirilen sözel etkileşimler yoluyla oluşmaktadır (Chin, 2006). Bu durumda öğretmenlerin bilgi sağlamaya yönelik olan söylemleri kadar ögrrencilerin birbirleri ile etkileşime girmelerine, iddialarını paylaşmalarına ve sağlıklı iletişim kurmalarına öncülük eden sınıf söylemine rehberlik edici öğretmen ifadeleri de öğretimsel süreçte büyük önem taşımaktadır (Leach ve Scott, 2002; Scott, 1998).

Öğretmen söylemleri sosyal etkileşime girilen ve sınıf içi uygulamaların olduğu birçok disiplinde ele alınmıştır. Özellikle fen eğitimi alanında yapılan söylem incelemeleri ve bunlardan Mortimer ve Scott (2003)'ın gerçekleştirdiği çalışma öğretmen söylemine ilişkin derinlemesine bir teorik çerçeve sunmaktadır. Bu teorik çerçeve kapsamında öğretmenlerin sınıf içi müzakerelerde sergiledikleri etkileşim örüntüleri; öğrenci ifadelerini değerlendirici, sunulan iddiaları açıklayıcı ya da genişletici ve takip sorusu yöneltici özelliklerine göre incelenmiştir. Öğretmenlerin öğrenci ifadelerine karşı sağladıkları cevapların ve sınıf söylemine yaptıkları müdahalelerin türevleri bu teorik çerçeveyi oluşturmaktadır.

Ulusal perspektifte sınıf içi tartışmalarda öğretmen müdahalelerini derinlemesine bir perspektif ile inceleyerek sınıf söylemi konu alanında birçok çalışma gerçekleştiren Soysal (2018a; 2018b; 2019a; 2019b;) öğretmenlerin söylemsel hamle türevlerine ilişkin teori ve veri temelli kataloglar oluşturmuştur. Oluşturulan kataloglar çeşitli disiplinlerde öğretimsel süreç yürüten öğretmenlerin söylemlerini incelemeye haiz olabildiği gibi okulöncesialanında uygulama gerçekleştiren öğretmenlerin de söylemlerini incelemek için uygun görülmektedir (ör., Soysal, 2019c; 2019d; 2020a; 2020b). Ancak bunların okul öncesi bağlamına uyarlanması ve okul öncesi sınıf ortamlarından gelen video temelli veriler aracılığıyla yeniden ele alınması gerekmektedir.

\section{Kuramsal Çerçeve}

\section{Etkileşim Örüntüleri Olgusu}

Öğretimsel faaliyetler esnasında öğrenciler için bilginin birincil kaynağını öğretmenin söylemleri ve öğretmen öğrenci arasındaki sözel etkileşimler oluşturmaktadır (Chin, 2006). Sözel etkileşimlerin öğrenme ve öğretme kavramları açısından önemi düşünüldüğünde sınıf söylemi ve sınıf içi etkileşimler çeşitli araştırmacıların ilgilendiği bir konu haline gelmiştir (Cazden, 2001; Chin, 2006; Edwards ve Mercer, 1987: Mehan, 1979; Mortimer ve Scott, 2003).

Sınıf içi etkileşimin bilinen örneklerinden biri olan ve üçlü diyalog olarak da adlandırılan (Lemke, 1990) "IRE" örüntüsü öğrenci ve öğretmen tarafından oluşturulan söylem mübadelesini temsil etmektedir. IRE (InitiateResponse-Evaluate); öğretmenin çoğunlukla örüntüyü bir soru aracılığıyla başlatması (initiate), öğrencinin öğretmen sorusuna cevap vermesi (response) ve öğretmenin öğrenci cevabını değerlendirmesi (evaluate) ile oluşmaktadır (Mehan, 1979). Aşağıda yer alan örnek yukarıdaki tanımı netleştirmektedir:
Öğretmen: Kış aylarında dışarı çıkarken bizi soğuktan koruması için hangi kiyafeti giymeyi tercih ederiz? (Initiate-Başlat) Ögrenci: Bere. (Response-Cevapla) Ögretmen: Tamam, onu başımıza takarız. (EvaluateDeğerlendir) / Başka?

Öğretmenin sınıf içi etkileşimi başlatmak üzere yönelttiği "Kış aylarında dışarı çıkarken bizi soğuktan koruması için hangi kıyafeti giymeyi tercih ederiz?" (initiate-başlat) sorusuna öğrencilerden birinin verdiği kısa "Bere." yanıtının (responsecevapla) üzerine öğretmenin "Tamam, onu başımıza takarız." ifadesi öğrenci tarafından verilen cevabı kabul ettiğini (evaluate-değerlendir) göstermektedir. Örüntü burada duraklamıștır ve sınıf içi etkileșimi tekrar bașlatmak için öğretmenin sınıf söylemine bir katkı yapması gerekmektedir. Öğretmen bunun üzerine "Tamam, onu bașımıza takarız." ifadesine ek olarak "Başka?" sorusunu yöneltir. Ek sorudan anlaşılacağı üzere öğretmen öğrencinin verdiği cevap ile tatmin olmamıştır ve duymak istediği cevabı almak için başlangıç sorusunu yineleyici bir soru yöneltmiștir (initiate-başlat) yani tekrar IRE örüntüsünü başlatmıştır. IRE örüntüsünün kendine özgü olan bu döngüsel formu iletişimsel yaklaşımlarda bahsedilen otoriter yaklaşım ile ilişkilendirilmektedir (Mortimer ve Scott, 2003). Bu örüntü türevinde öğretmen öğrenci cevaplarını değerlendirerek ulaşmak istediği cevap dışında kalan ifadeleri sınıf söyleminin dışında bırakmayı tercih etmekte böylece alternatif ya da çeşitlendirilmiş fikirlere yer vermemektedir.

Bu örüntüye alternatif olarak bilinen "IRF" örüntüsü ise öğrenci cevabının değerlendirilmesi yerine öğrenci cevabının derinleştirilmesine odaklanmaktadır (Mortimer ve Scott, 2003). IRF (Initiate-Response-Follow up) örüntüsü, öğretmenin sınıf içi etkileşimi başlatıcı sorusuna (initiatebaşlat) sağlanan öğrenci cevabının (response-cevapla) art alanını ortaya çıkarmak amacıyla öğretmenin sorduğu ek soru (follow up-takip sorusu) ile sürdürülür (Sinclair ve Coulthard, 1975). Önek olarak verilen diyalog bu örüntünün işlevini ortaya koymaktadır:

Öğretmen: Kış aylarında dışarı çıkarken bizi soğuktan koruması için hangi kiyafeti giymeyi tercih ederiz? (Initiate-Başlat) Ögrenci: Bere. (Response-Cevapla)

Ögretmen: Bere vücudumuzun hangi bölgesini soğuktan korur? (Follow up-Takip sorusu)

Ögrenci: Kafamızı. (Response-Cevapla)

Ögretmen: Sence soğuktan en çok korumamı gereken yer kafamiz mi? (Follow up-Takip sorusu)

Öğretmenin "Kış aylarında dışarı çıkarken bizi soğuktan koruması için hangi kıyafeti giymeyi tercih ederiz?" (initiatebaşlat) sorusuna bir öğrencinin "Bere." cevabı vermesi (response-cevapla) üzerine öğretmenin "Bere vücudumuzun hangi bölgesini soğuktan korur?" şeklinde bir karşılık vermesi (follow up-takip sorusu) ile öğrenci yanıtının derinine inmeye amaçlamıştır. Öğrencinin takip sorusuna verdiği "Kafamızı." yanıtının ardından öğretmen öğrencinin düşüncesini daha derinlemesine keşfetmek amacıyla "Sence soğuktan en çok korumamız gereken yer kafamı mı?" sorusunu yönelterek tekrar bir takip sorusu sorabilir. Görüldüğü üzere IRF örüntüsü I-R-F-R-F-R-F formu ile sürdürülebilmektedir bu nedenle öğretmen öğrencilere ait alternatif fikirleri keşfetmek amacıyla tekrar başlatıcı soru yöneltmeyebilir. Bu sayede öğretmen sorduğu takip soruları aracılığıyla öğrencilerin alternatif iddialarının ya da düşüncelerinin sınıf söyleminde yer alması konusunda onları teşvik etmektedir. Öğretmen IRF örüntüsü kullanımı ile diyalojik bir iletişimsel yaklaşımı ortaya koymakta ve desteklemektedir (Mortimer ve Scott, 2003). 
Söylemi işlevsel olarak diyalojik ya da otoriter yapan ise sınıf içinde yer alan fikirlerin hem öğretmen hem de öğrenciler tarafından ifade edilmesinden ziyade çeşitlendirilmiş ve farklı fikirlerin kabul görmesi ya da görmemesi ile ilişkilidir (Buty ve Mortimer, 2008). Diyalojik iletişimsel yaklaşımda tek bir fikre ya da sese odaklanmak yerine sınıf içinde birden fazla bakış açısına yer verilmektedir. Otoriter iletişimsel yaklaşımda ise çeşitlendirilmiş iddia ya da düşüncelere yer verilmesi ya da bunların keşfedilmesi amaçlanmaz (Mortimer ve Scott, 2003). Özetle, IRE ya da IRF formlarında olmak üzere etkileşim örüntüleri sınıf içi konuşmaların süregeldiği durumlarda öğrenci ve öğretmen arasında gerçekleşen iletişimsel alışverişin düzenlenme biçimine odaklanmaktadır.

Öğretimsel faaliyetlerin gerçekleştiği birçok disiplinde öğrenci ve öğretmen arasında gerçekleşen etkileşim örüntüleri araştırılmıştır. Scott, Mortimer ve Aguiar (2006) orta öğretim fen eğitiminde gerçekleşen söylemsel etkileşimi ortaya çıkarmak üzere sınıfta kullanılan diyalojik ve otoriter söylem yaklaşımlarını derinlemesine incelemişlerdir. Diyalojik ya da otoriter yaklaşım arasında yapılan tercihlerin ve bu iki yaklaşımı değişimli olarak kullanmanın önemini vurgulamaktalardır. Bu durumun öğrencilerin bilimsel bilgiyi anlamlandırmalarına ciddi bir katkı sağladığını ve öğretimsel sürecin böylelikle desteklendiğini savunmaktalardır. Otoriter yaklaşımın genel geçer ve kabul edilmiş bilimsel bilgiyi öğretimsel süreçte öğrencilere aktarmak konusunda kullanılması söz konusudur. Diyalojik yaklaşım ise otoriter yaklaşım ile filizlendirilmiş bilginin öğrenciler tarafından geliştirilmesine, farklı bakış açıları ile keşfedilmesine ve yeni bilgilerin paylaşılmasına hizmet etmektedir. Otoriter yaklaşımın diyalojik yaklaşım ile birlikte öğretimsel süreçlerde kullanılması öğrencinin bilgiyi anlamlandırılması ile ilişkilendirilmektedir (Scott vd., 2006). Araştırmada incelenen veri Mortimer ve Scott (2003)'ın analitik çerçevesi temel alınarak analiz edilmiştir ve sınıf içi sergilenen etkileşim örüntüleri incelenen iletişimsel yaklaşımın göstergesi olarak değerlendirilebilmektedir

Cullen (2002) gerçekleştirdiği çalışmasında yabancı dil öğretiminde ögrretmenlerin sergilediği IRF örüntülerini incelemiştir ve üçlü diyalog zincirindeki follow-up (sürdürme) hamlesinin hem değerlendirici hem de açıklaştırıcı işlevlerini ortaya koymuştur. IRE örüntüsünün öğretmen tarafından değerlendirici türde kullanılması temel ve kabul görmüş bilginin öğretimsel süreçte öğrenciye aktarılmasında rol oynamaktadır. Öğretmenin değerlendirici hamleler ile öğrenmeyi desteklenmesine ek olarak sınıf içinde gerçekleştirilen diyalogların hem billurlaştırılması hem de sınıf üyeleri arasındaki iletişimin kalitesinin arttırılması amacıyla öğretmen, öğrenci söylemlerini herkes için anlaşılabilirbirhale getirmeküzere açıklaştırabilir. Öğretmenin ifadeyi yeniden yapılandırması IRF örüntüsündeki followup hamlesinin açıklaştııı işlevine vurgu yapmaktadır. Yabancı dil öğretiminde follow-up hamlesini hangi işlevi ile kullanılacağına ilişkin kararın sınıf içi iletişimi doğrudan etkilediğini belirten çalışma sadece değerlendirici işlev sağlayan etkileşim örüntüsü (IRE) kullanımının öğretmen ile ögrenciler arasında yaşanan diyaloğu ve iletişimsel kaliteyi sekteye uğratacağını savunmaktadır. Bu durumun yanı sıra yüksek eğilimle öğrenci ifadelerini açıklaştırmaya yönelik kullanılan follow-up hamlesinin ise öğrencilerin kavramsal açıdan doğru olmayan ifadelerine dair eksiklikleri ya da yanlışları öğrencilerin fark etmeleri konusunda yardımcı olamayacağı belirtilmiştir (Cullen, 2002). Sınıf içi öğretimsel süreçte öğrencilerin söylemsel katkılarına öğretmenin sağladığı dönüşün hem değerlendirici hem de açıklaştırıcı follow-up hamleleri olması ve bu ikisi arasında denge kurulması gerektiğini belirten cullen (2002), açılklaştırıcı follow-up hamlelerinin çeşitli türlerde sergilenebildiğini ifade etmektedir. Bunlardan ilki öğrenci tarafından sınıf söylemine yapılan bir katkının iletişimsel açıdan yeterince anlaşılabilir olmadığı durumlarda öğretmenin 0 ifadeyi yeniden yapılandırması olarak belirtilmektedir. Başka bir türde ise öğretmen öğrencinin ifadesini genişletmek ve sınıf söyleminde daha etkili bir hale getirmek için zenginleştirerek sınıf söylemine katmaktadır, bu durum detaylandırma olarak ifade edilmektedir. Bir öğrenci ifadesinin ardından o ifadenin bağlamına dair öğretmenin gerçekleştirdiği bir ekleme yorumlama olarak görülmektedir. Bu tür, detaylandırmadan farklı olarak öğrencinin ifadesini daha zengin hale getirmek yerine, öğretmenin kendi düşünce sistemi ile oluşturduğu ve öğrenci ifadesine kattığı bir yorum olarak belirtilmektedir. Öğrenci tarafından sağlanan cevabın öğretmen tarafından yüksek sesle tekrar edilmesi ya da çok küçük bir değişiklik yapılarak sınıf söyleminde sunulması ile öğretmen yineleme yapmaktadır. Yineleme işlevsel olarak farklı özellikler gösterebilir, başka bir deyişle öğretmen öğrenci ifadesini tekrarlarken cevabı yüksek sesle tekrar ederek onaylıyor, soru tonlaması kullanarak sorguluyor ya da şaşırmış bir ses tonuyla ifadeye dair teyit talep ediyor olabilir. Görüldüğü üzere öğretmen IRF örüntüsünde öğretmen sınıf içi diyalogları sürdürmek amacıyla hem öğrencilerin öğretimsel süreçte bilgiyi edinmelerine (değerlendirici rol) hem de sınıf üyelerinin birbirleri ile sağlıkı iletişim kurmalarına (açıklayıcı rol) yaptığı tercihlerle ciddi katkılar sağlamaktadır.

IRE/IRF örüntüsünün fen eğitimi ve yabancı dil edinimi öğretimsel süreçlerinde araştırılmasının yanı sıra matematik eğitiminde de incelendiği görülmüştür. Üçlü diyalog örüntüsünü matematik eğitimi alanında araştıran Nassaji ve Wells (2000), öğrencilerin öğretimsel süreçte sağlanan içeriği anlamalarına IRE ve IRF örüntülerinin katkılarını incelemişlerdir. IRE (değerlendirici) ya da IRF (takip sorusu yöneltici) örüntü kullanmayı tercih etmenin öğretimsel süreçte farklı sonuçlara neden olduğu ve IRF örüntüsünü kullanmanın birden fazla yöntemi olduğu sonucuna ulaşmışlardır. Elde edilen bulgulara göre öğrenci cevaplarına karşılık olarak öğretmenin değerlendirici (IRE) ifade kullanması yerine takip sorusu (IRF) kullanması öğrencilerin konuya ilişkin görüşlerini ve varsayımlarını talep etmesi ile ilişkilidir. Bu nedenle öğretmenin IRF kullanımı sınıf içi konuşmalarda tartışılan konuya dair daha diyaloğa dayalı ve öğrencilerin düşüncelerini keşfedici bir tutum sergilemektedir (Nassaji ve Wells, 2000; Wells, 1999; 2000).

\section{Araştırmanın Gerekçesi ve Önemi}

Okul öncesi eğitimi alanında IRE ve IRF örüntüsünün incelendiği çalışmaların kısıtlı olmasıyla beraber Mascareño, Deunk, Snow ve Bosker (2017) okul öncesi öğretmenlerinin hikâye okuma ve değerlendirme etkinlikleri sırasında sergilenen üçlü diyalog örüntülerinin işlevlerini ve türlerini araştırmışlardır. Sınıf içi öğretimsel süreçlerde IRE ve IRF örüntülerinin işlevlerinin incelenmesinin yanı sıra bu örüntülerin açık ve kapalı soru özelliği gösterme, yönerge sağlama, öğrenci katkısını onaylama ve açıklayıcıdetaylandırıcı olma durumları analiz edilmiştir. Onaylama, reddetme, değerlendirme ve öğretmenin bilgiyi sağlayarak cevap vermesi IRE örüntüsü ile temsil edilirken, öğretmenin öğrenci cevaplarını detaylandırıcı katkıları ve öğrencilerin düşünmelerini sağlayacak fırsatlar tanıması, ipuçları vermesi ise IRF örüntüsü ile ilişkilendirilmiştir. Hikâye okuma etkinliklerinin öğretmenin talebiyle öğrenciler tarafından hem anlamsal açıdan hem de dilsel açıdan değerlendirildiği bu araştırmada öğretmenlerin onaylama işlevi gösteren ifadeler kullanarak yüksek oranda IRE örüntüsü sergilediği ortaya koyulmuştur. Hem anlamsal hem de dilsel açıdan hikâyelerin değerlendirildiği etkinliklerde ise öğretmenlerin detaylandırma amacıyla kullanılabilecek IRF örüntülerini çok nadir kullandıkları belirtilmiştir. 
Degotardi ve Han (2020) erken çocukluk eğitimi alanında gerçekleştirdikleri çalışmada iki yaş altındaki çocuklar (infant) ve eğitimcilerin sergilediği etkileşim örüntülerini derinlemesine incelemişlerdir. Çalışma kapsamında eğitimcilerin IRE ya da IRF örüntü çeşitlerinin kullanımının incelenmesinin yanı sıra çocukların cevaplarına (IRE ya da IRF'deki Response) ve eğitimcinin değerlendirme (IREevaluation) ya da açıklaştırarak sürdürme (IRF-follow-up) hamlesinden sonra çocukların yanıt verip vermediklerine (I-R-E-R ya da I-R-F-R'deki Response) dair bulgulara yer verilmiştir. Eğitimcilerin IRE/IRF örüntülerindeki başlatıcı (Initiation) söylemin bilgi sağlayan ya da bilgi sağlamayan özellik göstermesi ile çocukların sağladıkları katkılar arasında bir ilişki görülmediği belirtilmiștir. Fakat öncül çalıșmalarda (Mascareño vd., 2017) ortaya çıkan bulguların aksine Degotardi ve Han (2020)'ın çalışmasında eğitimciler IRE örüntüsüne kıyasla daha fazla IRF (açıklaştırarak sürdürme) örüntüsü sergilemişlerdir. Degotardi ve Han (2020) bu durumu çocukların sağladıkları katkının türü ne olursa olsun eğitimcilerin oluşan diyalog örüntülerinde bilgi sağlayıcı ve bilgiyi genişletici katkılar sağlama eğiliminde olmaları ile açıklamaktadır. Etkileşim örüntülerini okul öncesi eğitimi alanında inceleyen çalışmalar (Degotardi ve Han, 2020; Mascareño vd., 2017) dikkate alındığında IRE örüntülerinin öğrenen cevaplarını "değerlendirici", "doğrulayıcı" ya da "yanlışlayıcı" söylemsel özellikler gösterdiği; buna karşılık olarak IRF örüntülerinin hem açıklama/açıklaştırma hem de takip sorusu içerme özelliğinde olduğu görülmektedir. Bu söylemsel özellikler karşılaştırmalı ve birlikte incelendiğinde, bahsi geçen konuşma örüntülerindeki nicel değişimlerinin öğretimsel faaliyetlerin pedagojik-epistemolojik yöneylemi ile ilgili de bilgilendirici olabileceği düşünülmektedir. IRE temelli konuşma örüntülerinin daha çok bilgiyi merkeze alan ya da konu-merkezli ya da öğretmen-merkezli bir sınıf diyaloğunu karakterize ettiği söylenebilir (Mortimer ve Scott, 2003: Soysal, 2019d). IRF örüntülerinin "açıklama" ya da "takip sorusu" niteliği taşıması daha çok öğrenen sesine ya da iddialarına sınıf söyleminde yer verebileceğinden bu türdeki konuşma dizgelerinin daha öğrenen odaklı bir yöneylemi yansıttığı düşünülebilir. Bu çalışma bağlamında sınıf içi etkileşim örüntülerinin türevleri "değerlendirici", "açıklayıcı" ve "takip sorusu yönlendirici" şekilde ayrıştırılarak, karşılaştırmalı analizler aracılığıyla değerlendirildiğinden, katılımcı öğretmenlerin öğretimsel ya da pedagojik eğilimleri ya da yönelimleri de bilinebilecek ya da yorumlanabilecektir.

Etkileşim örüntüleri fen eğitimi ve yabancı dil edinimi alanında sıklıkla incelenirken diğer disiplinlerde de araștırımaktadır. Erken çocukluk eğitimi alanında ise etkileşim örüntülerinin incelendiği çalışmalara kısıtlı yer verilmektedir. Bu çalışma kapsamında etkileşim örüntülerinin derinlemesine incelenmesinin erken çocukluk eğitimi alanına katkı sağlayacağı düşünülmektedir. Bu çalışmanın sınıf içi öğretimsel faaliyetleri geniş bir zaman dilimi aralığında incelemesi, verileri birden fazla gruptan ve birden fazla öğretmenden elde etmesi, IRE ve IRF örüntülerinin değerlendirici, açıklayıcı ve takip sorusu yöneltici özelliklerini ortaya koyması araştırmanın önemini vurgulamaktadır. Ek olarak, öğrenci ve öğretmen arasında yaşanan diyalogların konuşma sıraları ve bunlara ilişkin örüntülere yer verilmesi bu çalışmayı erken çocukluk eğitimi alanında öncül araştırmalardan farklı kılmaktadır.

Bu amaç doğrultusunda okul öncesi öğretmenlerinin sınıf söylemine dayalı gerçekleştirdikleri etkileşim örüntülerinin ne olduğunu belirleyerek türlerini ve kullanım eğilimlerini incelemeyi amaçlayan bu araştırma;

1.Okul öncesi öğretmenleri sınıf içi diyalogları başlatma, sürdürme ve sonlandırma süreçlerinde hangi türde etkileşim örüntüleri kullanmaktalardır?
2. Okul öncesi öğretmenlerinin sınıf içi diyalogları başlatma, sürdürme ve sonlandırma süreçlerinde kullandığı etkileşim örüntülerinin eğilimi nedir? sorularına yanıt aramıştır.

\section{Yöntem}

\section{Araștırma Modeli}

Bu araştırma okul öncesi öğretmenlerinin sınıf içi uygulamalarındaki söylemlerini ve bu söylemlerle ortaya çıkan etkileşim örüntülerinin belirlenmiş bir çerçevede incelemesini kapsamaktadır. Öğretmen söylemlerinin ve etkileşim örüntülerinin derinlemesine betimlenmesi ve analiz edilmesi amaçlandığından bu araştırma bir durum çalıșması olarak tasarlanmıştır. Çalışma kapsamında birden çok öğretmenden veri toplanması ve verilerin çeşitlendirilmiş farklı uygulamalardan elde edilmesi nedeniyle araștırma, çoklu durum çalışması türü ile tanımlanmıştır (Merriam, 1998). Çoklu durum ya da kolektif durum çalışmaları incelenen konuya ilişkin derinlemesine bir anlayış sağlamak amacıyla birden çok durumu tanımlayıp karşılaştırabilmektedir (Creswell, 2012). Araştırma kapsamında iki okul öncesi öğretmeninin sınıf içi etkinliklerde sergilediği etkileşim örüntülerini incelemek amacıyla farklı zaman dilimlerinde gerçekleştirdikleri birden fazla etkinlikten veriler elde edilmiştir. Öğretmenlerin sınıf içi söylemlerinin derinlemesine incelenmesi için etkinliklerde sergilenen etkileşim örüntülerinin analizi gerçekleştirilmiştir, böylece örüntülerin neliği ve nasıllığı ortaya koyulmuştur. Sergilenen etkileşim örüntüleri hem öğretmen temelinde hem de öğretmenler arası karşılaştırmalar yapılarak incelenmiştir.

Durum çalışmaları, sıklıkla karşılaşıımayan ve sınırları belirlenmiş vakaları incelerken nicel analiz yöntemleriyle ve deneysel yaklaşımlarla fark edilmesi güç verileri ele alır. Bu verilerin kendini kolayca görünür kılmaması ve sezgilerden ayrıştırılmış bir şekilde belgelenmeye intiyaç duyması durum çalışmalarının önemini vurgulamaktadır (Merriam, 1998). Okul öncesi öğretmenlerinin sınıf söylemini odağına alan etkinliklere sıklıkla yer vermemesi nedeniyle araştırmacı tarafından çeşitli uygulamalar planlanmış ve bu uygulamaların öğretmenler tarafından öğrencilere sunulması sağlanmıştır. Elde edilecek verilerin öğretmen söylemine dayalı olması sebebiyle derinlemesine ve yorumlamacı bir perspektif ile analiz edilmesi gerekmiştir.

\section{Katılımcılar ve Araştırmanın Bağlamı}

Çalışmanın katıımcıları iki okul öncesi öğretmeni (Öğretmen Ayşe ve Öğretmen Bilge) ve 51 okul öncesi öğrencisinden oluşmuştur. 30'lu yaşlarının ortasında olan Öğretmen Ayşe; önlisans mezunudur, 11 senedir okul öncesi öğretmeni olarak görev yapmaktadır ve bulunduğu okulda iki senedir çalışmaktadır. Uç senedir aynı okulda çalışan Öğretmen Bilge; 20'lı yaşlarının ortasındadır ve önlisans mezunudur. Öğretmen Ayşe'nin sınıfında 60-72 ay aralığında olan 27 okul öncesi öğrencisi mevcuttur. Bu öğrencilerden 14'ü erkek $(\% 51,85), 13$ 'ü kIz $(\% 48,15)$ öğrencidir. Öğretmen Bilge'nin sınıfında 60-72 ay aralığında 25 okul öncesi öğrencisi bulunmaktadır ve bu öğrencilerden 14'ü erkek (\%56), 11'ı kızdır (\%44). Hem Öğretmen Ayşe'nin hem de Öğretmen Bilge'nin öğrenci gruplarında çeşitli dil gelişim düzeylerinde seyir gösteren çocuklar mevcuttur. Öğrencilerin Okul Öncesi Eğitim Programı (2013) Türkçe etkinlikleri kapsamında hikâye değerlendirme rutini ile sıkça karşılaşmalarına rağmen sınıf söylemine dayalı sınıf içi müzakereler konusunda deneyimleri kısıtıdır.

Öğretmenlerin öğrencileri ile iki yıl üst üste çalışmış olmaları; öğrencilerin gelişim ve kişilik özelliklerini, aileleri ile olan 
ilişkilerini ve akranlar arası oluşan dinamikleri geniş bir zaman diliminde gözlemlemelerini sağlamıştır. Öğretmen Ayşe'nin yaş ve kıdem olarak Ögrretmen Bilge'den daha tecrübeli olmasıyla birlikte, meslek hayatında uzun yıllar bulunmanın dezavantajına sahip olduğu gözlenmiştir. Ögrretmen Bilge'nin daha az meslek tecrübesi olmasının yanı sıra girişimci ve yeniliklere açık oluşu öğrencileriyle kurduğu iletişimde gözlemlenmiştir.

\section{Sınıf Içi Uygulamalar}

Araştırma kapsamında veri toplama aşamasına geçmeden önce kayıt altına alınacak olan sınıf içi uygulamaların tasarlanması ve planlanması konusunda çalıșmalar yapılmıştır. Belirlenecek uygulamaların sınıf içi tartışmalara imkân sağlaması, sınıf üyelerinin kritik edebileceği çeşitli durum ve olaylar sunması, öğretmene söylemlerini ve özellikle soru sorma becerilerini etkin bir şekilde kullanabileceği malzemeler vermesi gerekmiştir. Okul öncesi dönem çocuklarının dikkat sürelerini de göz önünde bulundurarak uygulamaların 15-20 dakikalık bir süreçte tamamlanması amaçlanmış. Bu süreç içinde öğrencilerin dikkatinin olabildiğince aktif bir düzeyde kalması için ilgi çekici vakalar tartışmayı bașlatmak, sürdürmek ve sonlandırmak üzere tasarlanmıştır. Öğrencilerin kritik etme, eleştirme, sorgulama ve değerlendirme gibi becerilerini kullanmalarına yol açacak hikâye durumlarını belirlemek amacıyla Piaget'nin (1932, çev. 2015) erken çocukluk dönemindeki bireylerin ahlaki yargılarını incelediği çalışmasından vaka örnekleri kullanılmıştır. Çocukların dünya ve nedenselliğe karşı bakış açılarını anlamak üzere Piaget, çeşitli yaş gruplarıyla görüşmeler gerçekleştirmiş ve onların ahlaki davranış ya da duygularını değil ahlaki yargılarının neler olduğunu tespit etmeye çalışmıştır. Görüştüğü çocuklara varsayımsal vaka örnekleri sunarak onlardan akıl yürütme becerilerini kullanmalarını talep etmiştir. Ayrıca bu yapılan çalışmaların farklı sosyal ortam, kültür ve yaş gruplarında uygulanmasının rastgele unsurlardan ayrıştırımasına olanak sağlayacağını belirtmiştir.
Tasarlanan hikâyelerin sınıf söylemine katkı sağlayacak katılımlara sebep olması için başlatıcı tartışma soruları belirlenmiştir. Veri toplanacak uygulamalar esnasında öğretmenlerin hikâyeyi öğrencilere sunmasının ardından araştırmacı tarafından belirlenmiş başlatıcı ana soruyu sorması istenmiștir. Tasarlanmış bu girișimin ardından gelecek ve oluşacak tartışma sürecinde öğretmenin kendi söylemlerini özgün bir şekilde olușturması talep edilmiștir. Araştırmacı tarafından tasarlanan ve öğretmene rehber olması amacıyla sunulan tartışmayı başlatan sorular ve hikâyelere ilişkin bilgiler Tablo 1'de görülmektedir. Buna ek olarak sınıf üyelerinin anlatılan hikâyeye ilişkin karakter ve nesneleri somutlaştırması için öğretmenin anlatımı ve tartışma sırasında kullanması amacıyla olayı, karakterleri ve objeleri temsil eden görseller araştırmacı tarafından belirlenmiştir. Görsel materyaller uygulama öncesinde öğretmenlere sunulmuştur.

\section{Veri Toplama ve Analiz Süreçleri}

Çalışma kapsamında toplanan verilerin ve bu veriler sonucunda ortaya çıkarılacak olan bulguların doğruluğunu meşrulaştırmak amacıyla veri toplama süreci ve araçları tasarlanmıştır. Veri toplama aşamasında öğretmenler sınıf söylemine dayalı uygulamaları gerçekleştirirken oluşan verinin sesi ve görüntüsü video kaydına alınmıştır. Veri toplama sürecine ilişkin etik kurul izni İstanbul Aydın Universitesi Etik Komisyonu'nun 17.12.2019 tarihli ve 2019/22 sayılı kararıyla alınmıştır. Ayrıca uygulamalar esnasında sınıf üyelerinin görüntü ve seslerinin video kayda alınmasına ilişkin öğretmenlerden ve öğrencilerin ebeveynlerinden onam formu alınmıştır. Uygulamalar boyunca elde edilen video tabanlı veriler toplam 17 etkinlik ve 302 dakikadan oluşmuştur. Öğretmen Ayşe veri toplama sürecinde 8 uygulama, Öğretmen Bilge ise 9 uygulama yapmıştır. Uygulama içerikleri başlığında değinilen beş farklı hikâye, ögretmenlerin oluşturduğu ve sayıları 10 ile 12 arasında değişen küçük öğrenci gruplarıyla sınıf içi etkinlik olarak gerçekleştirilmiştir. Öğretmenlerin tasarlanan uygulamaları kullanımına ilişkin bilgiler Tablo 2'de gösterilmiştir.

Tablo 1. Tasarlanan Hikâye Uygulamaları ve Tartışma Başlatıcı Sorular

\begin{tabular}{ccc}
\hline Hikâyenin İsmi & Hikâyenin İçeriği & Tartışmayı Başlatan Sorular \\
\hline & Karnı çok aç olan kız kardeşi Müge için pas- & \\
Hırsızlığın Gerekçesi & taneden poğaça çalan Ceren'in ve kırtasiyede & Sevgi ve Ceren'i yaptıklarını düşünerek; kim \\
& gezerken görüp çok beğendiği boya kalemlerini & haksızdır / kim daha haksızdır? \\
& gizlice çantasına koyan Sevgi'nin hikâyesi &
\end{tabular}

Mutfak kapısının arkasında 20 tane fincan

Göle Düşen Poğaça

Makas ve Köprü iliş̧kisi olduğunu bilmeyen ve kapıyı açtığında hepsini düşüren Hasan ile annesi evde yokken reçel kavanozunu almak üzere mutfak tezgâhına tırmanarak raftan bir fincan düşüren Kemal'in hikâyesi
Üç kızı ile göl kenarına giden bir annenin çocuklarına yaptığı poğaçalardan birer tane vermesi ve küçük kızın poğaçayı göle düşürmesinin hikâyesi
Sence yanlışlıkla 20 tane fincanı kıran Hasan mı hatalı, yoksa annesinden izinsiz mutfak dolabına tırmanıp bir tane fincan kıran Kemal mi hatalı?

Sen anne olsan bunlardan hangisini yapardın? "Küçük kıza hiç poğaça vermem", "Üç kıza da birer poğaça veririm" ya da "Küçük kıza bir poğaça veririm"

Emre'nin annesi izin vermemesine rağmen onun yokluğunu firsat bilip makasla oynaması ve ertesi gün kırık ve çürük olan köprüden geçerken aşağıdaki dereye düşmesinin hikâyesi
Yașça küçük öğrencilerin olduğu bir sınıfın büyük öğrenci grubundan ödünç kitap alması ve

Yırtılan Kitap kitaplara küçük sınıftan iki üyenin zarar vermesi sonucunda tüm küçük sınıf üyelerinin cezalandırııması hikâyesi
Sence büyüklerin küçüklere bir daha ödünç kitap vermeyecek olması doğru bir karar mı? 
Tablo 2. Öğretmenlerin Tasarlanan Uygulamaları Kullanımına ilişkin Bilgiler

\begin{tabular}{|c|c|c|}
\hline \multirow{2}{*}{ Uygulamanın İsmi } & \multicolumn{2}{|c|}{$\begin{array}{c}\text { Öğretmenlerin Uygulamaları } \\
\text { Kullanımı }\end{array}$} \\
\hline & Öğretmen Ayşe & $\begin{array}{l}\text { Öğretmen } \\
\text { Bilge }\end{array}$ \\
\hline Hırsızlığın Gerekçesi & $\sqrt{ } \sqrt{ }$ & $\sqrt{ }$ \\
\hline Kirılan Fincanlar & $\sqrt{ }$ & $\sqrt{ } \sqrt{ }$ \\
\hline Göle Düşen Poğaça & $\sqrt{ }$ & $\sqrt{ }$ \\
\hline Makas ve Köprü iliş̧kisi & $\sqrt{ }$ & $\sqrt{ } \sqrt{ }$ \\
\hline Yırtılan Kitap & $\sqrt{ } \sqrt{ }$ & $\sqrt{ } \sqrt{ }$ \\
\hline \multirow{2}{*}{ Toplam } & 8 & 9 \\
\hline & \multicolumn{2}{|c|}{17} \\
\hline
\end{tabular}

Öğretmenlerin sınıf söylemine dayalı gerçekleştirdiği uygulamalarda sergilediği etkileşim örüntüleri sosyokültürel söylem analizinin bir kolu olan sistematik gözlemle incelenmiştir. Söylem analizi geniş kapsamlarda dilin yazılı ya da sözlü ișlevleri ve daha fazlasıyla ilgilenirken; sosyokültürel söylem analizi, söylem analizinden farklı olarak sınıf gibi sosyal bir ortamda olușacak konușmaların ve zihinsel ürünlerin analizine odaklanmayı tercih etmektedir (Mercer, 2004). Ayrıca sosyokültürel söylem analizinde söylemi oluşturan üyelerin ifadeleri, müzakerelere ve birbirleri arasında etkileşimlere yol açtığından oluşturulan söylemin bağlamı analiz için esas alınır. Katıımcıların ifadeleri sosyal ortamda konuşulan konudan bağımsız bir öğe olarak değerlendirilemez, bağlam temelinde değerlendirilmeyi gerektirir. Sosyokültürel söylem analizinin daha çok nicel çıktılarına odaklanan sistematik gözlem yönteminde, katıımcının kullandığı her bir cümlenin sosyal bağlamı temel alınarak önceden belirlenmis kategorilere uyumu incelenir. inceleme sonucunda bir ifadenin ne olarak kodlanacağına karar verilir ve tüm kod atamalarının ardından olușan geniş tabloyu nicel perspektifle incelemek için kod ve kategorilere yönelik frekans ve yüzde hesaplamaları yapıır. Bu hesaplamalar sonucunda sistematik gözlem yöntemi ifadelerin oluşturulan sosyal bağlam temelinde nasıl bir eğilim gösterdiğini ortaya çıkarır (Mercer, 2004).

Öğretmenlerin oluşturduğu etkileşim örüntüleri sistemsel gözlemler sonucu oluşturulan öncül araștırmacıların çalışmalarındaki katalogları temel alarak, teori temelli bir perspektifle incelenmiștir. Analiz yönteminde teori temelli katalogların kullanımasının yanı sıra verinin sunduğu bu çalışma özelinde karșılașılan kodlamalara da yer verilmiștir. Bu durumda veri analizinde kullanılan kataloglar hem teori temelli hem de sadece bu verinin kendi doğasından ortaya çıkmış ve ona özgü olan veri temelli kodlar ile yapılandırılmıştır (Mercer, 2010).

Öğretmenlerin sergilediği etkileşim örüntülerinin neler olduğunu ve nasıl eğilimler gösterdiğini incelemek üzere elde edilmiş olan verideki ifadeler küçük parçalara ayrılmıştır. Ayrıştırılan küçük parçalar önceden belirlenmiş olan kategoriler ile ilişkilendirilerek kodlanmıştır. Deşifre edilmiş video tabanlı verilerdeki her bir öğretmen cümlesi kodlanacak bir birim olarak saptanmıştır. Etkileşim örüntülerini ortaya çıkarmak üzere öğrenci ifadelerini onların kullanmış olduğu belirtilmiştir fakat araştırma kapsamında hiçbir öğrenci ifadesi analiz edilmemiştir. Analiz edilmek üzere ifadelerin birimlere ayrılmasının ardından kullanılacak olan kodlama kataloğu belirlenmiştir ve yapılan kodlamaların sayımı ile analiz sonuçlandırılmıştır. Etkileşim örüntülerinin ortaya çıkarılması için iki farklı analiz yapılarak iki farklı örüntü türü incelenmişstir. Bunlardan biri öğretmen söylemlerinin değerlendirici ya da takip sorusu içerici nitelikte olması ile belirlenen üçlü etkileşim örüntüleri, diğeri ise ÖğretmenÖğrenci arasında oluşturulan TS (teacher-student) diyalog etkileşim örüntüleri olarak ele almıştır.

\section{Üçlü etkileșim örüntülerinin kodlanması}

Üçlü etkileşim örüntülerinin analizi, öğretmenlerin sınıf içi oluşan diyaloglarda öğrenci ifadelerine karşılık olarak kullandığı söylemlerinin konuşma akışındaki işlevini ortaya çıkarmak üzere yapılmıştır. Bu analiz için teori temelli olan Üçlü Etkileşim Örüntüsü Kataloğu (ÜEÖK) kullanılmıştır ve kataloğa ilişkin bilgiler Tablo 3'te görülmektedir. Öğretmen ifadesi üzerine öğrencilerden biri ya da birkaçının katkı yapması ve öğretmenin tekrar bir ifade kullanması ile oluşan söylemsel alışverişler Başlat-Cevapla-Değerlendir (BCD) ya da Başlat-Cevapla-Takip Sorusu (BCT) üçlü diyaloglar ile sergilenebilir (Sinclair ve Coulthard, 1975; Mehan, 1979). Sınıf içi uygulamaları analiz etmek üzere kullanılan ilk kod Başlat hamlesidir. Başlat, öğretmenin sınıf söylemini başlattığı, her uygulama başlangıcında tasarlanan hikâyeyi anlatarak başlatıcı soruyu sorma girişimidir. Öğretmenin sınıf söylemini başlatmasının ardından öğrencilerin sınıf söylemine katkıda bulunduğu her ifade Cevapla hamlesi olarak değerlendirilmiştir. Üçlü diyaloğun karakterini belirleyecek olan öğretmen ifadesi ise Başlat ve Cevaplanın ardından gelir ve bunlar Değerlendir ya da Takip Sorusu olabilir. Öğrenci tarafından sağlanan cevabı değerlendirmek üzere kullanılan bir öğretmen ifadesi Değerlendir olarak kodlanmıştır. Buna alternatif olarak bir öğrenci cevabı ya da ifadesinin ardından öğretmen bu cevaba ilișkin açıklaștırma ya da derinleştirme talep edebilir. Öğretmenin bu talep ile sorgulayıcı bir ifade kullanması ise Takip Sorusu olarak kodlanmıștır (Soysal, 2019d). Bu durumda öğretmenin başlatıcı olarak kullandığı ifade dıșında kullandığı tüm ifadeler BCD ya da BCT olarak kodlanmaya açıktır. Bu üçlü diyaloglara ek olarak, öğrenci tarafından verilen bir cevabı değerlendirmenin ötesinde öğretmenin açıklaştırdığı ya da bir öğrenci ifadesine karşıık olarak öğretmenin kendi fikrini beyan ettiği hamleler Açıkla (BCA) olarak kodlanmıştır. BCA ile öğretmen, öğrenci ifadesini değerlendirmenin ilerisine geçerek derinlemesine ve yorumlamacı bir ifade ortaya koymuştur. Bu araştırma kapsamında kullanılan BCA üçü diyaloğuna öncel çalışmaların katalogları teori temelli bir şekilde kılavuzluk etmişstir (Soysal, 2019d). Ayrıca bu araştırma özelinde toplanan verilerin sağladığı çıktılar BCA'nın özelliklerine katkıda bulunarak bu kodlamanın veri temelli oluşuna katkı sağlamıştır. Bu araştırma bir durum çalışması olmasına rağmen analiz işlemleri için gömülü teori desen türlerinden biri olan sistematik desenin işlem basamakları veri analiz sürecinde temel alınmıştır. Sistematik desenin ilk basamağı olan açık kodlama ile öğretmenin her bir ifadesi küçük bir birim olarak kodlanmak üzere ayrıştırılmıştır (Goulding, 1999). Kodlanmak istenen ve ayrıştırılmış öğretmen ifadesi, öncül çalışmaların kataloglarını temel alarak onların bünyesinde bulunan kategorilerden biriyle ilişkilendirilmiştir. Açık kodlama sonucu ayrıştırılmış ifadenin, temel alınan ÜEÖK'daki bir kategori ile ilişkilendirilerek ifadenin neyi temsil ettiğine karar verilmesi ise eksenel kodlama basamağı olarak tanımlanmıştır (Creswell, 2012).

\section{TS diyalog etkileşim örüntülerinin kodlanması}

TS diyalog etkileşim örüntülerinin analizi, sınıf içi müzakereler esnasından öğretmenin sınıf söylemine ne sıklıkta müdahale ettiğini ortaya koymak amacıyla gerçekleştirilmiştir. Bu amaçla uygulamalar esnasında kullanılan tüm ifadeler deşifre edilmiş ve aynı zamanda ifadeyi kullanan kişinin öğretmen ya da öğrenci olduğu deşifre metinlerinde belirtilmiştir. Sınıf içi diyalogların akışında yaşanan konuşma sıraları göz önünde bulundurularak T-S örüntüleri ortaya 
Tablo 3. Üçlü Etkileşim Örüntüsü Kataloğuna (ÜEÖK) Ilişsin Kodlar ve Açıklamalar

\begin{tabular}{|c|c|}
\hline Kod & Kodun Açıklaması \\
\hline Başlat & Öğretmen sınıf içinde konuşulacak olan konuya ilişkin tartışmayı başlatacak soruyu sorar. \\
\hline Cevapla & Öğretmene ya da sınıf arkadaşına cevaben bir öğrencinin sağladığı cevap ya da sınıf söylemine kattığı ifade \\
\hline Değerlendir (BCD) & Bir öğrenci ifadesinin ardından öğretmenin bu ifadeyi değerlendirmesi \\
\hline Açıkla (BCA) & $\begin{array}{l}\text { Bir öğrenci ifadesinden sonra öğretmenin ifadeyi açıklaştırması ya da kendi fikrini ortaya koyması ile oluşan } \\
\text { açıklayıcı özellikler taşıyan öğretmen ifadesi }\end{array}$ \\
\hline Takip Sorusu (BCT) & $\begin{array}{c}\text { Bir öğrenci cevabının ardından gelen ve bu cevabın ötesine geçmek amacıyla öğretmenin açılaştırma ya da } \\
\text { derinleştirme işlevleri taşıyan bir soruyu sınıfa yöneltmesi }\end{array}$ \\
\hline
\end{tabular}

çıkarılmıştır. Öğretmenin ifadesi "T" ile kodlanırken herhangi bir öğrenci ifadesi "S" ile kodlanmıştır. Bu sayede sınıf içi konuşmalarda öğretmen ve öğrenci ya da öğrenci ve öğrenci arasında yaşanan diyalogların örüntü türleri belirlenmiştir. TS örüntülerinde örüntü türünün belirlenmesi için öğretmenin müdahalesi esas alınmıştır; başka bir deyişle, öğretmenin her bir ifadesi örüntünün başlangıcını oluşturmuştur (Soysal, 2020a).

\section{Geçerlik ve Güvenirlik}

Bu çalıșma kapsamında analizlerden elde edilen bulguların ve yorumlamaların inandırıcılığının ve güvenirliğinin artırılması için birtakım önlemler alınmıștır. Öncelikle tüm etkileşim örüntülerinin kodlanması esnasında kodlayıcılar arası güvenirlik katsayıları hesaplanmıştır. Başlangıçta 0.80 üzerinde bulunan Cohen kappa katsayısı (Burla vd., 2008), uyuşma sağlanamayan öğretmen söylemlerinin varlığında, kodlayıcılar arası sürekli müzakereler aracıığıyla 0.90 üzerine çıkarılmıștır. Bu çalıșmaya dahil olan araștırmacılardan biri tüm uygulamalar boyunca uygulama sınıfında yer almıştır ve öğretmenlerlebirlikteöğretimselsürecemüdahalesiolmadan pasif olarak katıım göstermiştir. Bu durum araştırmacılardan en az birinin veri toplama aracına belli bir dereceye kadar dönüștüğünü göstermektedir (Creswell vd., 2007). Dolayısıyla araştırmacılardan birinin verilerin analizi ve yorumlanması süreçlerinde tamamlayıcı ve telafi edici rolü belli bir dereceye kadar garantilenmiştir. Bu çalışmada betimlenen sınıf içi uygulamalar, veri toplama, analiz ve yorumlama süreçleri başka araştırmacılar tarafından tekrarlanabilir ya da başka okul öncesi sınıf içi öğretimsel süreçlere ve faaliyetlere transfer edilebilir. Çünkü araştırmacılar, önceki kısımlarda da gösterildiği üzere, araștırma bağlam ve metodolojisini derinlemesine betimlemiş ya da tüm açıklığıyla dış okuyucu ile paylaşmışladır ki nitel çalışmalarda genellemeyi ve metodolojik transferi dış okuyucular yapmaktadır (Denzin ve Lincoln, 2008) (ör., diğer araştırmacılar, diğer okul öncesi öğretmenleri). Ek olarak, çalışmanın geçerliliğini artırma noktasında katıımcı kontrolü de sağlanmaya çalışılmıştır. Gözlemlenen tüm etkileşim örüntüleri katılımcı öğretmenlerle paylaşılmış, araştırmacıların veri analizi ve yorumlamaları ile ilgili anlamlıı̉ ve akla yatkınlık durumları katılımcılar tarafından kontrol edilmiş ve onaylanmıştır (Denzin ve Lincoln, 2008).

\section{Araştırmanın Etik Izin Bilgileri}

Yapılan bu çalışmada "Yükseköğretim Kurumları Bilimsel Araştırma ve Yayın Etiği Yönergesi" kapsamında uyulması belirtilen tüm kurallara uyulmuştur. Yönergenin ikinci bölümü olan "Bilimsel Araştırma ve Yayın Etiğine Aykırı Eylemler" başlığı altında belirtilen eylemlerden hiçbiri gerçekleştirilmemiştir.

\section{Etik kurul izin bilgileri}

Etik Değerlendirmeyi Yapan Kurul Adı: İstanbul Aydın Üniversitesi

Etik Değerlendirme Kararının Tarihi: 17.12.2019

Etik Değerlendirme Belgesi Sayı Numarası: 2019/22

\section{Bulgular}

\section{Etkileşim Örüntülerine Ait Nitel Bulgular}

Etkileşim örüntülerinden biri olan "Üçlü Etkileşim Örüntü"sünde öğretmenin öğrencilerin ifadelerine ne türde karşılıklar verdiğine ve bu karşılıkların öğrenci ifadelerini değerlendirici ya da onların ifadelerini ortaya çıkarıcı rollerde olup olmadığına ilişkin incelemeler yapılmıştır. Diğer etkileşim örüntüsü olan "Öğretmen - Öğrenci Konuşma Sırası Etkileşim Örüntü"sünde öğretmenin hangi sıklıkla sınıf söylemine müdahalede bulunduğu açıklanmıştır. Her bir etkileșim örüntüsü türevi tanımlanarak açıklanmıș ve sınıf içi etkinliklerden söylemsel alıntılar yapılarak örneklendirilmiştir.

\section{Üçlü etkileşim örüntüleri}

\section{Başlat - Cevapla - Değerlendir (BCD) üçlü etkileșim örüntüsü}

Öğretmen; üzerinde tartıșılacak bir durum, konu ya da olay sunarak sınıf üyelerinin katkı sağlayacağı sınıf söylemini oluşturmak amacıyla etkinliği başlatacak bir soruyu öğrencilere yöneltmiştir, bu soru BCD $\left(B_{\text {aslat }} C_{\text {evapla }} D_{\text {eğerlendir }}\right)$ üçlü etkileşim örüntüsündeki "Başlat" söylemidir. Bu başlatıcı soruya diyalogu devam ettirecek olan bir sınıf üyesinin verdiği yanıt BCD üçlü etkileșim örüntüsündeki "Cevapla" söylemini temsil etmektedir. Öğretmenin öğrenciye karşılık olarak, ek bir açıklama yapmadan öğretim ajandasını temel alarak bu cevabı kritik etmesi ya da bu cevabın ardından diyalogu sürdürmeyi sağlamayacak bir ifadede bulunması BCD üçlü etkileşim örüntüsündeki "Değerlendir" söylemine işaret etmektedir. Araştırma kapsamındaki "Başlat" söylemi öğretmen tarafından her uygulama için etkinlikleri başlatmak üzere bir kez ifade edilmiştir. Öğrencilerin verdiği her bir yanıt ise "Cevapla" söylemi olarak belirtilmiştir. "Başlat" ve "Cevapla" etkileşimlerine ilişkin örnekler Tablo 4'de verildiği üzere öğretmen sınıf söylemindeki tartışmaya kapı açacak olan hikâyeyi anlamıştır ve bu hikâyeye ilişkin tartışmayı başlatacak soruyu öğrencilere yöneltmiştir (Şıra 1; T). Öğretmenin etkinliği başlatmak için hikâyeyi anlatması ve tartışmayı ateşleyecek ilk soruyu sorması bu çalışma kapsamında her zaman "Başlat" söylemi olarak belirtilmiştir. Ögrretmene ya da diğer sınıf üyelerine karşı olarak bir ögrenci tarafından ifade edilmiş söylem ise "Cevapla" olarak gösterilmiştir (Sıra 2; S1). Öğrencilerin sınıf söylemine yaptığı her katkı bu araştırma kapsamında "Cevapla" söylemi olarak görülmüştür. BCD üçlü etkileşim örüntüsündeki 
üçüncü ve örüntünün tanımını belirleyici söylem olan "Değerlendir" Tablo 4'de verildiği üzere öğretmen tarafından öğrenci cevabını kabullenici bir işlevle kullanılmıştır (Sıra 20; T). Öğrencilerden birinin göle düşen poğaçanın gölden çıkartıldığında yenilip yenilemeyeceğine dair ifadesi (Sıra 19: Sg) hakkında öğretmen öğrencinin cevabını onaylar bir şekilde karşılamıştır ve bu onaylama, cevabın öğretmen tarafından kritik edilmesi sonucu oluşmuştur. Öğretmenin "Değerlendir" söylemi sınıf içi tartışmanın sürdürülebilirliğini sağlamamasından dolayı öğrenci ve öğretmen arasında yaşanan etkileşim kesilerek son bulmuştur. Öğretmen, Sg'ün verdiği bu cevaba (Sıra 19) ilişkin detaylı açıklama talep etmemiştir ya da bu yanıttan yola çıkarak başka bir soru yöneltmemiştir, bu nedenle öğretmenin "Değerlendir" söylemi ile "BCD" (B-C-...-C-D formunda) etkileşim örüntüsü sınıf söyleminde yer bulmuştur.

\section{Başlat - Cevapla - Açıkla (BCA) üçlü etkileşim örüntüsü}

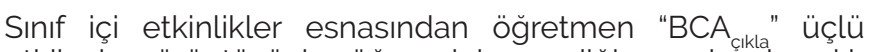
etkileşim örüntüsüyle öğrencinin verdiği cevabà karşılık olarak; bu cevabı diğer sınıf üyeleri için aydınlatan, pekiştiren ya da yorumlayan "Açıkla" ifadesi ile sınıf söylemine katkıda bulunmuştur. Öğretmen "Değerlendir" ifadesinden farklı olarak "Açıkla" ifadesinde öğrenci cevabına ilişkin bir yargı belirtmek durumunda değildir. BCA üçlü etkileşim örüntüsünün tanımını belirleyici olan "Açıkla" ifadesi öğretmenin, öğrenci söylemlerini daha anlaşıı bir hale getirmek istediği ya da sınıf söyleminde yer alan bir ifadeye ilişkin kendi fikirlerini izah etmeyi tercih ettiği durumlarda kullanılmıştır. Öğretmen "Açıkla" ifadesini kullanarak öğrencilerin söylemlerini iletişime uygun bir formatta düzenleyerek tekrar sınıf söylemine katmak ya da kendi yargılarını detaylandırarak öğrencilere aktarmak amacında olmuştur. BCA üçlü etkileșim örüntüsünde "Açıkla" ifadesinin öğrencilerden bir yanıt gelmesini talep etmemesi nedeniyle bu örüntüde öğretmen - öğrenci arasındaki etkileşimin sürdürülebilirliğinin olmadığı görülmüştür. Tablo 5'de görüldüğü üzere poğaçası göle düşen küçük kıza bir poğaça daha verilip verilmemesi hakkında bir tartışma sürdürülmektedir. S6g'ün fazla kalan poğaçayı anne ve babanın bölüşmesine ilişkin ifadesinden (Sıra 203) sonra öğretmen önce bu ifadeyi onaylayarak değerlendirmiş (BCD) ardından öğrenci ifadesinin herkes tarafından anlaşılırlığını arttırmak amacıyla ifadeyi yeni bir formatta (Sıra 204; T) sınıf söylemine sunarak görünür kılmıştır (BCA). Sınıf söyleminin ilerleyen aşamalarında öğretmen, S76'nın küçük kıza poğaça verilmezse karnının doymayacağına ilişkin ifadesini (Sıra 217) onaylamıştır (BCD) ve öğrencinin ifadesini hem desteklemiş hem de kendi öznel düşüncesini ortaya koymuştur (BCA) (Sıra 218; T). Öğretmen "Açıkla" ifadesiyle kazaların karşılaşılması olası durumlar olduğunu vurgulayarak kendi yargılarını sınıf söylemine katmıştır. Fakat "Açıkla" ifadesi içeren BCA üçlü etkileşim örüntüsü (B-C-...-C-A formunda) öğretmen - öğrenci arasında oluşan diyaloğu sürdürme konusunda yetersiz kaldığından dolayı öğretmen bu ifadesinin ardından bir soru yönelterek diyaloğun devam etmesini sağlamıştır.

Tablo 4. Üçlü Etkileşim Örüntülerindeki "Başlat", "Cevapla" ve "Değerlendir" (BCD) Söylemlerinden Alıntı

\begin{tabular}{|c|c|c|c|}
\hline Sıra & Konuşan & Söylem & Etkileşim Örüntüsü \\
\hline 1 & T & $\begin{array}{c}\text { Evet, çocuklar bakalım bugün nasıl bir hikâye ile karşılaşacağız. Bir annemiz var ve üç tane } \\
\text { kızı var. Üç kızıyla birlikte anne göl kenarında pikniğe gidiyor çocuklar... Ve her kızına bir tane } \\
\text { poğaça veriyor. Kızlardan küçük olan yanlışlıkla poğaçayı elinden düşürüyor. Siz olsanız şu } \\
\text { an ne yapardınız böyle bir durumda? / Emine? }\end{array}$ & Başlat \\
\hline 2 & S1 & Onu hemen tutardım. & Cevapla \\
\hline 3 & $\mathrm{~T}$ & Anne olsaydınız ne yapardınız? Kızın annesinin yerinde olsaydınız ne yapardınız? & Takip Sorusu \\
\hline 4 & S2 & Yenisini verirdim. & Cevapla \\
\hline 5 & $\mathrm{~T}$ & Önder? & - \\
\hline 6 & S3 & Üfleyip verirdik. & Cevapla \\
\hline 7 & $\mathrm{~T}$ & Poğaçayı üfleyip verirdin. / Zerrin Nur senin bu konudaki fikrin? & Açıkla / Takip sorusu \\
\hline 8 & S4 & Yeniden, yeni başka bir tane verirdim. & Cevapla \\
\hline 9 & $\mathrm{~T}$ & Yeni bir poğaça mı verirdin kıza? & Takip Sorusu \\
\hline 10 & S4 & Evet. & Cevapla \\
\hline 11 & $\mathrm{~T}$ & Bir poğaça daha verirdin. / Barış sen ne düşünüyorsun? & Açıkla / Takip sorusu \\
\hline 12 & S5 & Poğaçayı düşürürse yıkamaları gerekti. & Cevapla \\
\hline 13 & $\mathrm{~T}$ & Peki, yıkanınca poğaça yenilebilir mi? & Takip sorusu \\
\hline 14 & Ss & Hayır. & Cevapla \\
\hline 15 & $\mathrm{~T}$ & Nasıl olur, poğaça nasıl bir şey? & Takip sorusu \\
\hline 16 & S7 & Yumuşak. & Cevapla \\
\hline 17 & $\mathrm{~T}$ & Üzerine su gelirse yenilebilir mi tekrardan? & Takip sorusu \\
\hline 18 & S8 & Hayır. & Cevapla \\
\hline 19 & S9 & Tadı bozulur. & Cevapla \\
\hline 20 & $\mathrm{~T}$ & Evet, tadı bozulabilir. & Değerlendir \\
\hline
\end{tabular}

Not: Öğretmen Ayșe ile yapılan 4. uygulama, Göle Düşen Poğaça, Ekim, 2019, Video deşifre. 'T: Öğretmen, "*S4: Öğrenci-4 
Tablo 5. Üçlü Etkileşim Örüntülerindeki "Açıkla" (BCA) ve "Takip Sorusu" (BCT) Söylemlerinden Alıntı

\begin{tabular}{|c|c|c|c|}
\hline Sira & Konuşan & Söylem & Etkileşim Örüntüsü \\
\hline 203 & S69 & Bir tanesi fazla kalırsa birisini de anneler ve babalar yer birisini de onlar da çocuklar yer. & Cevapla \\
\hline 204 & $\mathrm{~T}$ & $\begin{array}{c}\text { Tamam. / Kalan poğaçaları bölüşürüz diyorsun. Bir tanesini anne bir tanesini baba yer, diğer } \\
\text { poğaçaları da çocuklar yer. / Cemil senin başka bir düşüncen var mı bu konuyla ilgili? / Peki, } \\
\text { sizce küçük kız hatalı mı bu konuyla ilgili? }\end{array}$ & $\begin{array}{c}\text { Değerlendir / Açıkla / } \\
\text { Takip sorusu }\end{array}$ \\
\hline 205 & Ss & Hayır. & Cevapla \\
\hline 206 & T & Bilerek mi düşürmüş poğaçasını yere? & Takip sorusu \\
\hline 207 & Ss & Evet. & Cevapla \\
\hline 208 & $\mathrm{~T}$ & İsteyerek mi düşürmüş poğaçasını? & Takip sorusu \\
\hline 209 & Ss & Hayır. & Cevapla \\
\hline 210 & $\mathrm{~T}$ & Böyle kazalar olabilir mi? & Takip sorusu \\
\hline 211 & Ss & Evet. & Cevapla \\
\hline 212 & $\mathrm{~T}$ & Bu durumda küçük kıza bir poğaça vermek hatalı mı, sizce hatasız mı? & Takip sorusu \\
\hline 213 & Ss & Hatalı. & Cevapla \\
\hline 214 & $\mathrm{~T}$ & Bir poğaça daha vermek hatalı mı küçük kıza? & Takip sorusu \\
\hline 215 & Ss & Hayır. & Cevapla \\
\hline 216 & $\mathrm{~T}$ & Yani istemeden düşürdü ya küçük kız poğaçayı... / Eğer poğaçayı vermezsek ne olur? & Açıkla / Takip sorusu \\
\hline 217 & S76 & Karnı doymaz. & Cevapla \\
\hline 218 & $\mathrm{~T}$ & $\begin{array}{c}\text { Aç kalır. Aç kalır değil mi? / Bazen böyle kazalar istemsiz kazalar olabilir. O yüzden annesinin } \\
\text { ona bir poğaça vermesi hatalı bir davranış mı değil mi diye sordum. / Hatalı bir davranış mı, } \\
\text { doğru bir davranış mı? }\end{array}$ & $\begin{array}{c}\text { Değerlendir / Açıkla / } \\
\text { Takip sorusu }\end{array}$ \\
\hline 219 & S77 & Hayır. & Cevapla \\
\hline 220 & S78 & Doğru bir davranış. & Cevapla \\
\hline
\end{tabular}

Not: Öğretmen Ayşe ile yapılan 4. uygulama, Göle Düşen Poğaça, Ekim, 2019, Video deşifre. 'T: Öğretmen, " SSs: Öğrenciler

\section{Başlat - Cevapla - Takip Sorusu (BCT) üçlü etkileșim örüntüsü}

Sınıf içi etkinlikler sırasında öğretmen "BCT " üçlü etkileşim örüntüsünü kullanarak (1) sınıf soylemindeki diyalogların sürdürülebilirliğini arttırmak, (2) öğrencilerin ifadelerinin art alanındaki noktalara ulașmak, (3) sınıf üyelerinin tartışma içeriğini takip edebilmesini desteklemek, (4) sınıf söyleminde kullanılan bir ifadenin kritize edilmesini talep etmek, (5) karşı argümanlar olușturmak ya da karșı argümanların varlığını sorgulamak, (6) öğrencilerin basit gözlemler, karșılaștırmalar ya da tahminler yapmasına sebep olmak, (7) tartışılan konuya ilișkin öğrencilerin çeşitli çıkarımlarda bulunmalarını sağlamak ve (8) öğrencilerin kendi iddialarını destekleyici deliller sunmalarını istemek amaçlarıyla sorular yöneltmiştir ve bu soru ifadeleri "Takip sorusu" olarak belirtilmiştir. Ögretmen sınıf içi etkinliklerde "Takip sorusu" yönelterek öğrencilerin tartıșılan konu, durum ya da olaya ilişkin fikirlerini sorgulamış ve sınıf söyleminde öğrenci söylemlerinin öğretmen söylemine göre daha sık yer almasına fırsat tanımıştır. Öğretmenin "Takip sorusu" kullanması öğretmen - öğrenci arasında geçen diyalogların kesilmeden sürdürülmesine ve tartışmanın derinleștirilmesine katkı sağlamıștır. Tablo 5'de görüldüğü üzere poğaçasını göle düşüren kızın bu konuda hatalı olup olmadığına ilișkin bir tartıșma sürdürülmektedir. Öğretmen, S6g'ün cevabına (Sıra 203) karşı değerlendirici ve açıklayıcı ifadeler kullandıktan sonra tartıșmanın devamını sağlamak amacıyla bir takip sorusu yöneltmiştir (Sıra 204; T). Öğretmen ve öğrenciler arasında devam eden diyaloglar "B-C-...-TC-T-C-T..." örüntü zinciri ile sürdürülmüş (Sıra 205-215) ve öğretmenin bilgilendirici bir ifade kullanmasının ardından diyaloğun devamını sağlamak amacıyla tekrar "Takip sorusu" yöneltilmiştir (Sıra 216; T). Öğretmen BCT üçlü etkileşim örüntüsünü sergileyerek öğrenci söylemlerinin sınıf söyleminde aktif ve yoğun bir şekilde yer almasına sebep olmuş ve öğrenci ifadelerinin derinlerine inilmesini sağlamıştır.

\section{Öğretmen - Öğrenci (T-S) konuşma sırası etkileşim örüntüleri}

Sınıf içi faaliyetler esnasında yapılan tartışmalarda "öğretmen - öğrenci" ve "öğrenci - öğrenci" arasında diyaloglar gerçekleştirilmiştir. Konuşma (söz hakkı alma) sıralarında kimin yer aldığı ve bu sıraların örüntülerinin nasıl olduğuna ilişkin bilgiler "Öğretmen - Öğrenci (T-S [Teacher - Student]) etkileșim örüntüleri" olarak incelenmiștir. Öğretmenin sınıf söylemine kattığı bir ifadeden sonra bir öğrencinin sözü alması ve ardından araya bașka bir öğrenci girmeden öğretmenin bir ifade daha kullanması ile öğretmen - öğrenci konușma bu örüntüsü "T-S-T-S-..." formu ile belirtilmiștir Bu örüntüye alternatif olarak öğretmen tartışma esnasında bir ifade kullandıktan sonra diyaloğa bir öğrencinin katkı yapması ve ardından öğretmenin bir müdahalesi olmadan başka bir öğrencinin diğer sınıf üyelerine cevap vermesi ya da fikrini beyan etmesi ile öğretmen - öğrenci - öğrenci örüntüsü ("T-S-S" ya da "T-S-S-..." formunda) şeklinde gösterilmiştir. Sınıf söyleminde oluşan etkileşim örüntülerinde öğretmenin öğrenci - öğrenci arasında oluşacak diyaloglara araya girmeden müdahale etmesi ya da etmemesi "T-S" örüntülerinin nasıl olduğunu belirlemektedir "T-S" örüntülerindeki belirleyici unsur öğretmenin sınıf söylemine ne sıklıkla katkıda bulunduğu olmuştur. Tablo 6'da görüldüğü üzere öğretmen (Sıra 139) sınıf üyelerinden birinin verdiği cevabın art alanına ulașmak amacıyla o sınıf üyesine bir soru yöneltmiştir. Buna yanıt olarak S44 soruya ilişkin bir cevap düşündüğünü belirtmiştir (Sıra140) (T-S). Öğretmen 
Tablo 6. Öğretmen - Öğrenci (T-S) Etkileşim Örüntü Türevlerine Ilişkin Alıntılar

\begin{tabular}{|c|c|c|c|}
\hline Sira & Konuşan & Söylem & Etkileşim Örüntüsü \\
\hline 139 & $\mathrm{~T}$ & $\begin{array}{l}\text { Küçük olunca az mı yemesi gerekiyor? Neden peki? Neden Ahmet Umut? Düşün bakalım } \\
\text { neden böyle bir şey söyledin ben çok merak ettim. Her şeyin bir nedeni vardır, bunun da bir } \\
\text { nedeni var. Neden böyle düşündün? }\end{array}$ & T-S \\
\hline 140 & $\mathrm{~S} 44$ & Düşünmeye çalışıyorum. & \\
\hline 141 & $\mathrm{~T}$ & Küçük çocuklar az mı yerler? Küçük oldukları için acaba, böyle olmuş olabilir mi? Olur mu? & T-S-S \\
\hline 142 & $\mathrm{~S} 45$ & Olur mu? Haydi söyle, Ahmet Umut? & \\
\hline 143 & S46 & Küçük olan az yemiş. & \\
\hline 144 & $\mathrm{~T}$ & Neden peki? & \multirow{6}{*}{ T-S-S-S-S-S } \\
\hline 145 & $\mathrm{~S} 46$ & Çünkü onlar büyükler. & \\
\hline 146 & S47 & Çünkü o küçük olduğu için onun büyümesi için daha fazla yemeli. & \\
\hline 147 & $\mathrm{~S} 48$ & Mesela 16 tane falan yemesi lazım. & \\
\hline 148 & S49 & Sekiz tane mi var poğaça? & \\
\hline 149 & $\mathrm{~S} 48$ & On altı tane yemesi lazım. & \\
\hline 150 & $\mathrm{~T}$ & $\begin{array}{c}\text { Başka bir şey söylemek isteyen var mı? Başka bir şey söylemek isteyen var mı çocuklar? } \\
\text { Peki, teşekkür ederim. }\end{array}$ & \\
\hline
\end{tabular}

Not: Öğretmen Bilge ile yapılan 4. uygulama, Göle Düşen Poğaça, Ekim, 2019, Video deşifre. *T: Öğretmen, **S44: Öğrenci-44

S44'ten yanıt alamayınca sorusunu tüm sınıf üyelerine yönelterek onların kritik etmesini talep etmiştir (Sıra 141). Bu soruya ilişkin önce S45 ardından S46 sınıf söylemine katkıda bulunmuştur ve bu iki öğrencinin ifadelerinin arasında öğretmen müdahalesi bulunmamaktadır (Sıra 142-143) (T-S-S). Ardından öğretmen tekrar sınıf söylemine bir katkıda bulunarak öğrencilerden birine soru yöneltmiştir (Sıra 144; T). Bunun üzerine S46, S47, S48 ve S49 öğretmen müdahalesi olmadan kendi aralarında bir diyalog geliştirmişstir (Sıra 145146-147-148-149). Öğrenci - öğrenci arasında gelișen bu diyalog örüntüsünde (T-S-S-S-S-S) öğrenciler birbirlerinin ifadelerine karşılık vermek yerine kendi fikirlerini bağımsız bir şekilde sunmuşlardır ve bu yaşanan diyalogda öğretmen müdahalesi öğrencilere ait olan beş söylemden sonra gerçekleşmiştir.

\section{Etkileșim Örüntülerine Ait Nicel Bulgular}

\section{Üçlü etkileşim örüntü türevleri ve eğilimlerine ilişkin bulgular}

Elde edilen veriler sonucunda Öğretmen Ayşe ve Öğretmen Bilge'nin sınıf içi etkinlikler esnasında sergiledikleri üçlü etkileşim örüntü türevlerinin ve eğilimlerinin kısmi farklılıklar gösterdiği sonucuna ulaşılmıştır. Öğretmenlerin kullandıkları üçlü etkileşim örüntü türevleri ve eğilimleri Şekil 1 ve Şekil 2'de görülmektedir.

Şekil 1 incelendiğinde, Öğretmen Ayşe'nin sınıf içi konuşmalar esnasında sergilediği üçlü etkileşim örüntülerinin kullanım eğilimi $\left(X_{B C D}=\% 7,79\right),\left(X_{B C A}=\% 35,06\right)$ ve $\left(X_{B C T}=\% 57,15\right)$ şeklinde olduğu görülmüştür. Şekil 2 incelendiğinde, Öğretmen Bilge'nin sınıf içi konuşmalar esnasında sergilediği üçlü

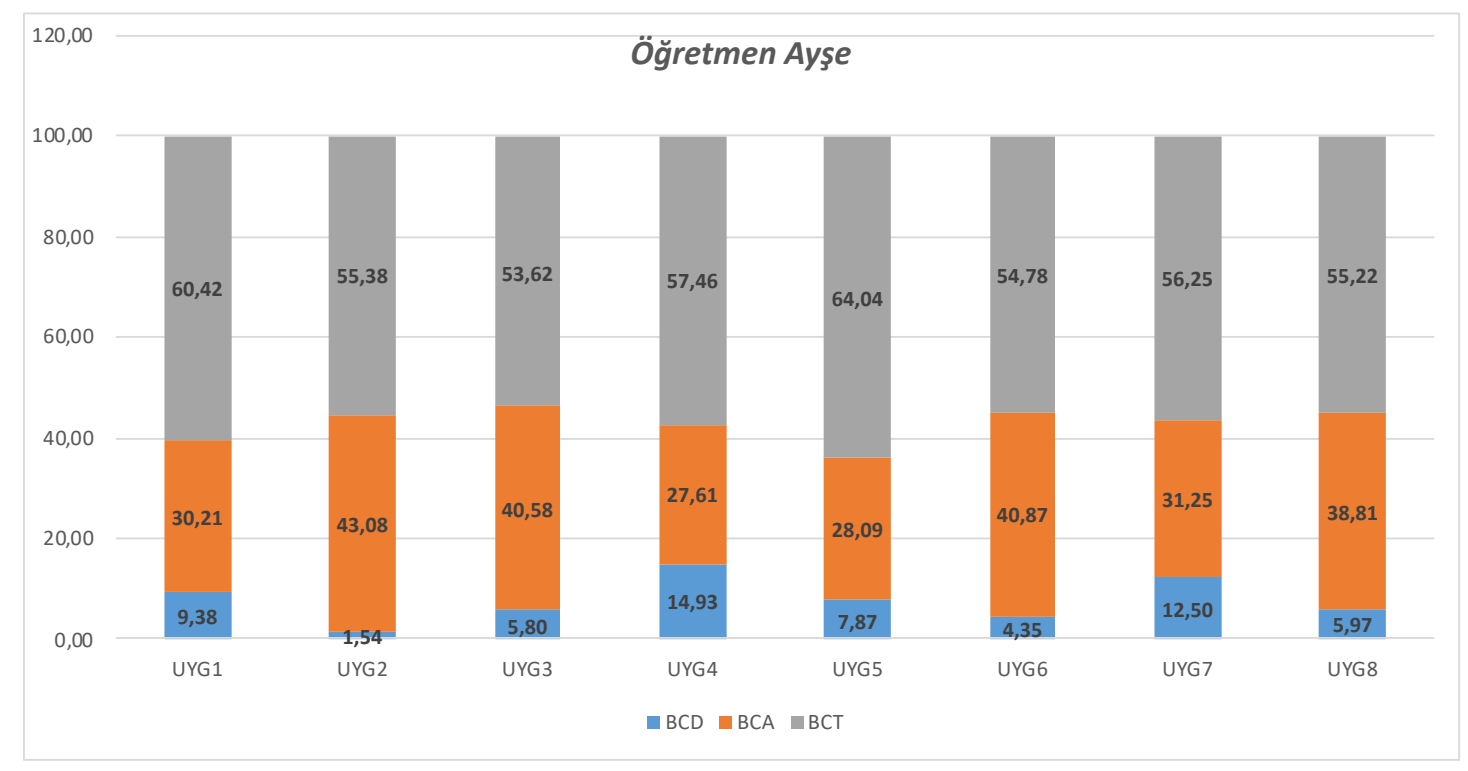

*BCD: Başlat - Cevapla - Değerlendir; BCA: Başlat - Cevapla - Açıkla; BCT: Başlat - Cevapla - Takip sorusu; UYG1: Uygulama

Şekil 1. Öğretmen Ayşe'nin üçlü etkileşim örüntü türevlerini kullanma eğiliminin yüzdelik değerleri - 1 


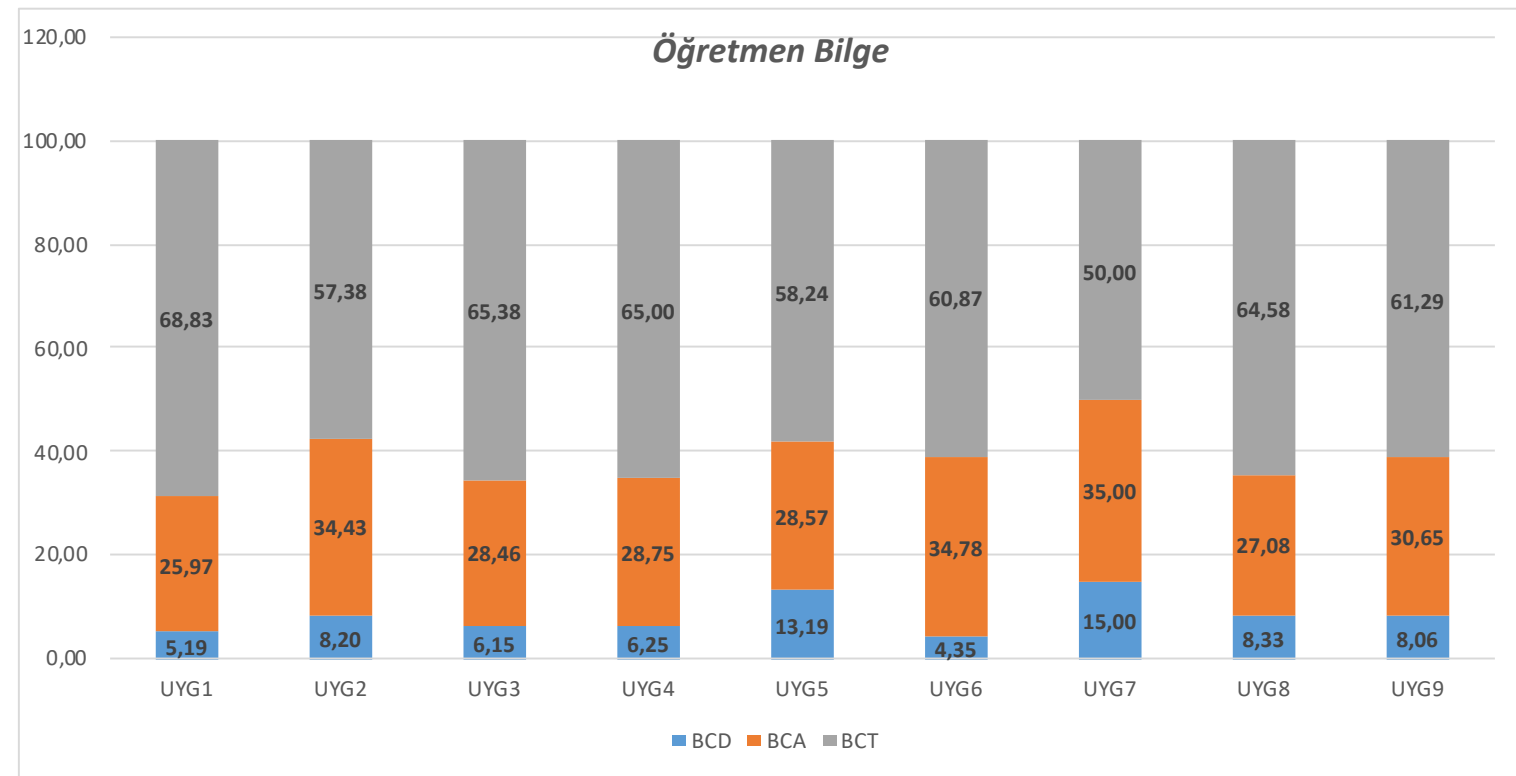

*BCD: Başlat - Cevapla - Değerlendir; BCA: Başlat - Cevapla - Açıkla; BCT: Başlat - Cevapla - Takip sorusu; UYG1: Uygulama - 1

Şekil 2. Öğretmen Bilge'nin üçlü etkileşim örüntü türevlerini kullanma eğiliminin yüzdelik değerleri

etkileşim örüntülerinin kullanım eğilimi $\left(X_{B C D}=\% 8,30\right),\left(X_{B C A}=\right.$ $\% 30,41)$ ve $\left(X_{B C T}=\% 61,29\right)$ şeklinde olduğu görülmüştür. Başka bir deyişle hem Oğretmen Ayşe hem de Oğretmen Bilge sınıf söyleminde kullandığı 10 ifadenin altısında takip sorusu sorarak sınıf içi tartışmaların sürdürülebilirliğini sağlamış, öğrencilerin cevapları ve düşüncelerinin art alanını öğrenme girişiminde bulunmuştur. Buna ek olarak öğretmenlerin kullandığı 10 ifadeden dördü sınıf içi tartışmalarda öğrencilerin sağladıkları cevabı değerlendirici ya da bu ifadeleri ve/veya kendi düşüncelerini açıklayıcı-derinleştirici söylemlerden oluşmuştur. Bu bulgular sonucunda öğretmenlerin sınıf içinde kullandıkları ifadelerin yarısından çoğunun takip sorusu olduğu fakat öğrenci söylemlerini değerlendirdikleri ya da sınıf söylemindeki ifadeleri açıklaştırdıkları söylemlere sıklıkla yer verdiği görülmüştür.

"T-S" konuşma sırası etkileşim örüntü türevleri ve eğilimlerine

\section{ilişkin bulgular}

Elde edilen veriler sonucunda Öğretmen Ayşe ve Öğretmen Bilge'nin sınıf içi etkinlikler esnasında sergiledikleri "T-S" konuşma sırası etkileşim örüntü türevlerinin ve eğilimlerinin kısmi farklııklar gösterdiği sonucuna ulaşılmıştır. Öğretmenlerin kullandıkları "T-S" etkileşim örüntü türevleri ve eğilimleri Şekil 3 ve Şekil 4'te görülmektedir.

Şekil 3 incelendiğinde Öğretmen Ayşe'nin sınıf içi konuşmalar esnasında sergilediği "T-S" etkileşim örüntülerinin kullanım eğilimi $\left(X_{\text {TS } \% 93.66}\right)$ ve $\left(X_{\text {TSS }}+X_{\text {TSSS }}+X_{\text {TSsss }}=\% 6,34\right)$ şeklinde olduğu görülmüştür. Şekil 4 incelendiğinde Ögretmen Bilge'nin sınıf içi konuşmalar esnasında sergilediği "T-S" etkileşim örüntülerinin kullanım eğilimi $\left(X_{T S}=\% 93,58\right)$ ve $\left(X_{\text {TSS }}+X_{\text {TSSS }}+\right.$ $\left.X_{T S s s s}+X_{T s s s s s}+X_{T(S \times 30)}=\% 6,42\right)$ şeklinde olduğu görülmüsştür.

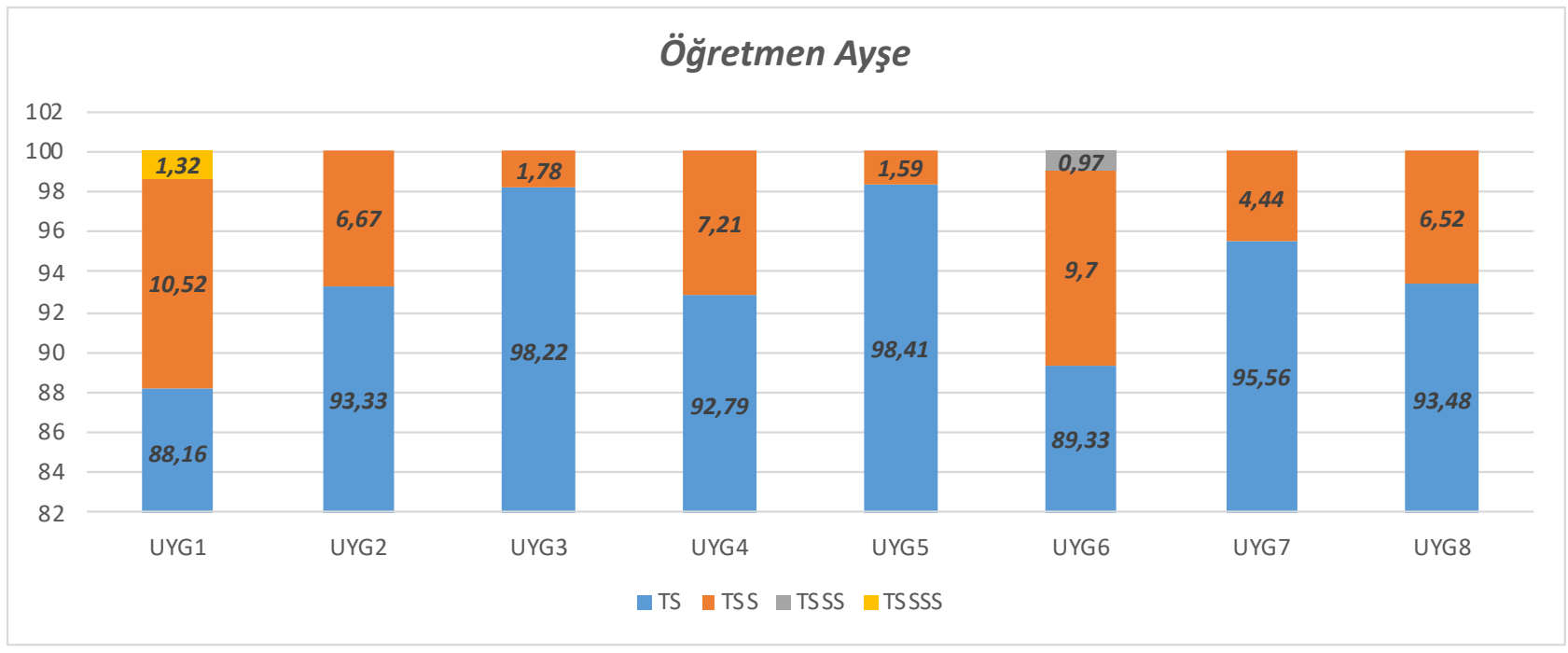

*TS: Öğretmen - Öğrenci; TSS: Öğretmen - Öğrenci - Öğrenci; TSSS: Öğretmen - Öğrenci - Öğrenci- Öğrenci; TSSSS: Öğretmen - Öğrenci - Öğrenci Öğrenci - Öğrenci; UYGı: Uygulama - 1

Şekil 3. Öğretmen Ayşe'nin "T-S" etkileşim örüntü türevlerini kullanma eğiliminin yüzdelik değerleri 


\section{Öğretmen Bilge}

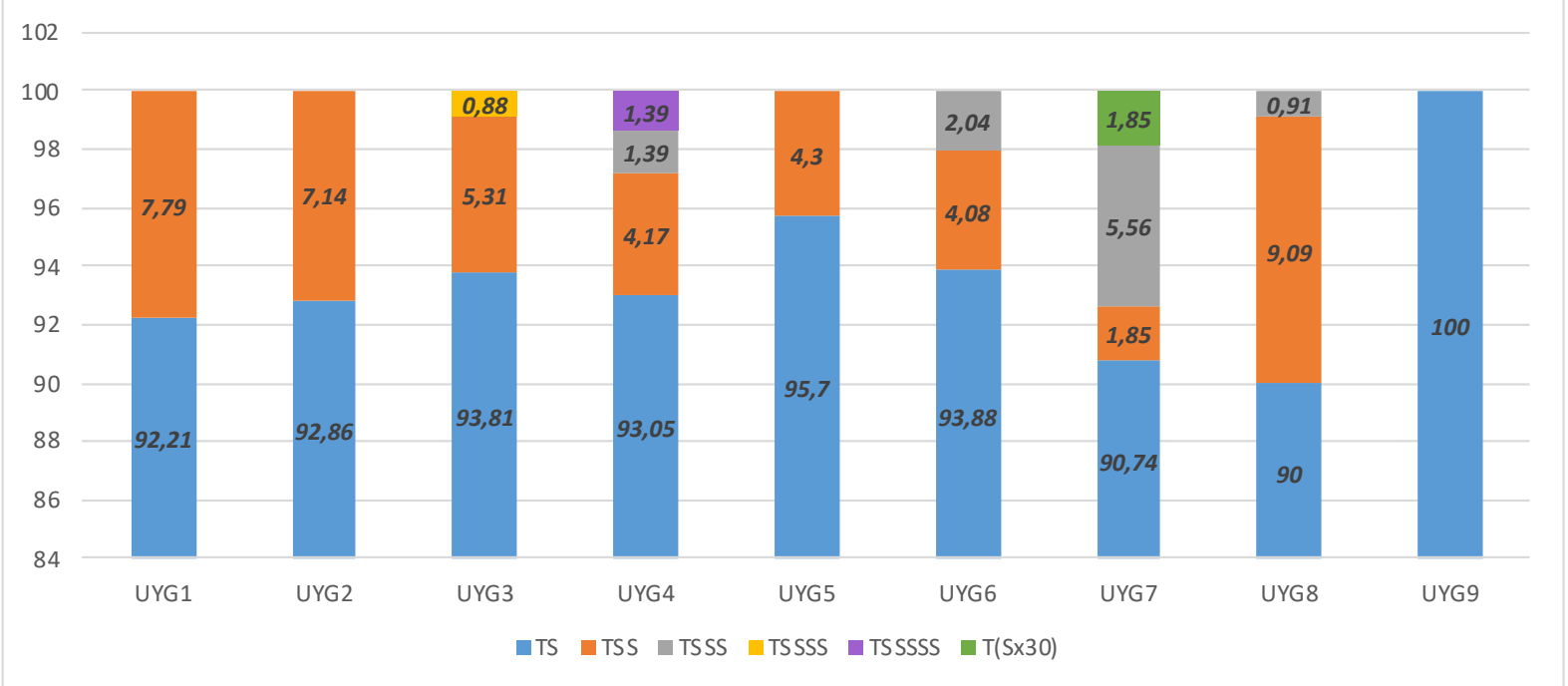

*TS: Öğretmen - Öğrenci; TSS: Öğretmen - Öğrenci - Öğrenci; TSSS: Öğretmen - Öğrenci - Öğrenci- Öğrenci; TSSSS: Öğretmen - Öğrenci - Öğrenci Öğrenci- Öğrenci; TSSSSS: Öğretmen - Öğrenci - Öğrenci - Öğrenci - Öğrenci - Öğrenci; T(S×30): Öğretmen- Öğrenci - ... - Öğrenci (30 öğrenci diyaloğu); UYG1: Uygulama - 1

Şekil 4. Öğretmen Bilge'nin "T-S" etkileşim örüntü türevlerini kullanma eğiliminin yüzdelik değerleri

Başka bir deyişle hem Öğretmen Ayşe'nin hem de Öğretmen Bilge'nin sınıf söyleminde kullandığı 100 ifadeden 94'ünün, tek bir öğrencinin sınıf söylemine katkıda bulunmasının ardından yapılan öğretmen müdahalesi olduğu sonucuna ulaşıımıştır. Bunun yanı sıra öğretmenlerin sınıf içi etkinlikler sırasında kullandıkları 100 ifadeden sadece altısı öğrenci öğrenci arasında geçen çeşitli örüntülerdeki diyaloglardan sonra oluşmuştur. Bu bulgular öğretmenlerin öğrenci - öğrenci arasında oluşacak etkileşimlere müdahalede bulunduğunu ya da öğrenci - öğrenci diyaloğunu arttıracak ifadeler kullanmaktan kaçındığını göstermiştir.

Öğretmen Ayşe ve Öğretmen Bilge'nin sınıf içi etkinlikler esnasında kullandığı etkileşim örüntü türevleri ve kullanma eğilimleri incelendiğinde iki öğretmenin de ifadelerinin yarısından fazlasının takip sorusundan (BCT) oluştuğu fakat sıklıkla değerlendirici (BCD) ve açıklayıcı (BCA) ifadeler kullandıkları görülmüştür. Buna ek olarak öğretmenlerin sınıf söylemindeki diyaloglara çoğunlukla müdahale ettiği ve öğrenci - öğrenci arasında oluşan etkileşimlerin çok kısıtlı olduğu bulgusuna ulaşılmıştır.

\section{Tartışma}

Bu araștırma kapsamında okul öncesi öğretmenlerinin sınıf içi konuşmalarda sergilediği etkileşim örüntüleri iki farklı türde incelenmiştir. Bunlardan biri öğretmen öğrenci diyaloğunun konuşma sırasını ifade eden T-S konuşma sırası örüntüsü iken diğeri ise öğretmenlerin öğrenci cevaplarına karşıık olarak kullandıkları değerlendirici, açıklayıcı ya da takip sorusu yönlendirici rollerini ifade eden üçlü etkileşim örüntüleri olarak belirlenmiştir.

Öğretmenlerin sergilediği T-S konuşma sırası örüntüleri öğretmenlerin sınıf içi tartışmalardaki diyaloglara ne sıklıkla müdahalede bulunduğunu ortaya koymaktadır. "T-S-T-S" şeklinde oluşturulan bir diyalog örüntüsünde öğretmenin her öğrenci cevabından sonra diyaloğa katkı sağladığı görülürken "T-S-S-S-T" şeklinde oluşan bir diyalog örüntüsünde öğretmenin müdahalesi olmadan üç öğrencinin birbirleri arasında diyalog oluşturduğu görülmektedir. Bu araştırma kapsamında elde edilen bulgular sonucunda hem
Öğretmen Ayşe hem de Öğretmen Bilge'nin sıklıkla "T-S-T-S" konuşma sırası örüntüsü sergilediği belirlenmiştir. "T-S-T-S" konuşma sırası örüntüsü dışında kalan örüntü sıralarının daha nadir sergilenmesi nedeniyle öğrenci-öğrenci arasında yaşanan diyalogların sınırlı şekilde oluştuğu görülmüştür. Bu nedenle sınıf içi oluşan diyaloglarda öğretmenlerin sınıf söylemine sıklıkla müdahale ettiği sonucuna varılabilir.

T-S-T-S örüntüsünün yani öğretmen müdahalesinin sık olması ve öğrenci-öğrenci arasında yaşanan diyaloglar ile kısıtlı sayıda karşılaşılması sınıf içi öğrenmenin öğrenciler ile aktif bir şekilde yapılandırılmadığına işaret etmektedir. Bu durum öğrenci - öğrenci arasında yaşanan diyaloğa ve doğal bir sonucu olarak iş birliği ile öğrenmenin yapılandırılmasına alan aç(a)mamaktadır (Hing-Hu vd., 2021; Muhonen vd., 2020). "T-S-T-S" örüntülerinin yoğun kullanımı öğrencilerin öğretmen sorularına yanıt vermekle yükümlü olduklarını ve öğretmen dışındaki sınıf üyeleri ile etkileşime girerek sınıf söylemini yönlendirmediklerini göstermektedir. Bu durum sınıf içi tartışmanın çoğunlukla öğretmen tarafından yönlendirildiğini ve öğretmenin rehberlik ettiği akışa öğrencilerin yönlendirici bir rol ile değil, katkı sağlayıcı bir rol ile dahil olduklarını ortaya koymaktadır. Öğretmenlerin sınıf söylemine yaptıkları yoğun müdahale, yaşanan diyalogların otoriter bir yaklaşımla oluşturulduğuna işaret etmektedir (Brandvoll-Haukenes, 2014; Matengu vd., 2020; Mortimer ve Scott, 2003). Öğretmenin öğrenci-öğrenci arasında yaşanacak diyaloğa alan açmayarak sınıf söylemine sıklıkla müdahalede bulunması, bazı öğrenci katkılarını geri planda tutması ve hedeflediği öğretimsel amaca hizmet eden öğrenci katkılarını ise ön plana çıkarması ile ilişkilendirilebilir (Oosterhoff, 2020; Zhou ve Hedges, 2020).

Dolayısıyla sergilenen bu etkileşim örüntüleri, diğer çalışmalarda da gösterildiği üzere (ör.; Brandvoll-Haukenes, 2014; Hing-Hu vd., 2021; Matengu vd., 2020; Muhonen vd., 2020), monolojik bir fikir değişimi sürecini göstermektedir. Öğrenci merkezli bir anlayıştan yola çıkarak oluşturulan sınıf söylemindeki etkileşim örüntülerinin öğretmen-öğrenci arasında olmasının yanı sıra öğrenci-öğrenci arasında oluşturulması da beklenmektedir (Soysal, 2020a). Elde edilen bulgular sonucunda Öğretmen Ayşe ve Öğretmen Bilge'nin 
Tablo 7. Öğrenci-Öğrenci Arasında Yaşanan TS Konuşma Sırası Etkileşim Örüntüsünden Alıntı

\begin{tabular}{|c|c|c|}
\hline Sira & Konuşan & Söylem \\
\hline 47 & $\mathrm{~T}$ & $\begin{array}{c}\text { Ne yapması gerekiyordu şuradan şöyle mi geçmesi gerekiyordu? (Köprünün yıpranmış kısmını es geçmesi gerektiği- } \\
\text { ni göstererek) }\end{array}$ \\
\hline 48 & S15 & Evet, yani burasını görmemeleri gerekiyordu şuradan dikkatli bir yerden geçmesi gerekiyordu. \\
\hline 49 & S16 & Öğretmenim simit alırdı böyle. Peki, burası mavi mi? \\
\hline 50 & S15 & Hayır, orası siyah ama şuralardan düşebilirdi en son. \\
\hline 51 & S17 & Ama burası mağaraya benziyor. \\
\hline 52 & S15 & Mağara değil orası ama oradan sonra düşebilirdi. \\
\hline 53 & $\mathrm{~S} 18$ & Artık biz de konuşmak istiyoruz. \\
\hline 54 & S15 & Ondan sonra... \\
\hline 55 & S17 & Çünkü orası açık olabilir. \\
\hline 56 & S15 & $\begin{array}{l}\text { Bak ya buradan düşseydi pis suya o zaman hasta olurdu ölürdü giderdi. Ağaçtan düşseydi mecburen ama çocuk } \\
\text { makasla oynasaydı yani oynadığı için elini kesebilirdi. Oynamak ne yani oynasaydı çok dikkatli bir yeri kopardı kanardı. }\end{array}$ \\
\hline 57 & S19 & Etini koparırdı. \\
\hline 58 & S15 & Ondan sonra karnı giderdi ondan sonra bacağı kopardı, etini koparırdı ondan sonra ayakkabısını bazen keserdi. \\
\hline 59 & $\mathrm{~S} 20$ & Burak yeter artık. \\
\hline 60 & S15 & Ya kafası kesilseydi o zaman \\
\hline 61 & $\mathrm{~S} 21$ & Hatta şuradan böyle boynu kesilseydi \\
\hline 62 & S15 & Boynu kesilseydi kafası kesilseydi ölüp giderdi. \\
\hline 63 & S22 & Dikiş atıırdı birkaç gün öyle kalırdı. \\
\hline 64 & $\mathrm{~S} 23$ & Kulağını kesseydi. \\
\hline 65 & S15 & Kulağını kesseydi. \\
\hline 66 & S24 & Gözünü kesseydi. \\
\hline 67 & $\mathrm{~S} 15$ & Gözünü kesse zaten iki gözünü kesse zaten kör olur ölür. \\
\hline 68 & S 25 & Hayır, gözlerini kesemez. \\
\hline 69 & S26 & Ağzını kesseydi. \\
\hline 70 & $\mathrm{~S} 15$ & Ağzını kesse konuşamaz. Kulağını kesse duyamaz. \\
\hline 71 & $\mathrm{~S} 27$ & Duyar duyar. \\
\hline 72 & $\mathrm{~S} 28$ & Burnunu kesse nefes alamaz. \\
\hline
\end{tabular}

\begin{tabular}{ccc}
\hline 73 & S15 & $\begin{array}{c}\text { Evet, ağzını da o yüzden bura bura bura bura bura bura (uzuvlarını işaret ediyor) çok önemli. Ve kulaklar her taraf çok } \\
\text { önemli. }\end{array}$ \\
\hline 74 & S29 & Peki, şuradaki burnundan kafasını kesebilirdi. \\
\hline 75 & S30 & Saçını kesebilirdi. \\
\hline 76 & S15 & Saçını kesse bir şey olmaz ki zaten. \\
\hline 77 & S31 & Burak zaten şu an biz saçlarımızı kestiriyoruz. \\
\hline 78 & T & Peki, arkadaşlar bu konu hakkında... / Önder, ne demek istiyorsun? \\
\hline 79 & S32 & Köprü kırık olduğu için köprünün iki tarafına da tabela koyabilirlerdi. \\
\hline
\end{tabular}

Not: Öğretmen Bilge ile yapılan 7. uygulama, Makas ve Köprü, Ekim, 2019, Video deşifre, "T: Öğretmen, "S15: Öğrenci-15

sınıf içi etkileşimlerdeki sık müdahalesini sınıf söylemini yönlendirme amacıyla sergilediği söylenebilir. Katılımcı öğretmenlerin sınıflarında sosyal-entelektüel etkileşimin ve karşılıklı fikir değişiminin olduğundan bahsedilebilir. Bu sınıf söylemi tablosu dışarıdan incelendiğinde bir diyalojik söylemler dizisinin olduğunu gösterebilir. Ancak bulgular kısmında da gösterildiği üzere bu etkileşimlerin alternatif akıl yürütme ya da açıklama biçimlerini değil, öğretmenin öğretim ajandasında yer alan belirli durumları ve söylem biçimlerini yansıttığı söylenebilir (Oosterhoff, 2020; Zhou ve Hedges, 2020). Bu anlamda diyaloglaştırma ve felsefileştirme teorilerine atıfyapılabilir (Caivd., 2020). Gerçek bir diyalog "T-S-
T-S" örüntülerinin olup olmamasından bağımsız bir şekilde ortaya çıkabilir (Soysal, 2019d). Diyaloğun varlığı alternatif bir dil-düşünsel sistem olarak öğrenenlerin söylemlerinin varlığına bağlıdır (Gäreskog ve Lindqvist, 2020). Bu çalıșmada da gösterildiği üzere, sosyal-sözel etkileşim diyalojik öğretimi ya da öğrenen-merkezli öğretimi garantilemez (Soysal, 2020a). Bu tarzda bir öğretimin garantisini ancak ve ancak, ister T-S-T-S ister T-S-S-S... örüntüsü şeklinde belirsin öğretmenlerin alternatifli akıl yürütme tarzlarını kabul edil etmediği belirler (Soysal, 2020a). Ancak öğretmenlerin sınıf söyleminde oldukça yoğun bir şekilde T-S-T-S örüntüsünü var etmesi öğretimsel sürecin belli bir dereceye kadar 
monolojik ya da konu-merkezli ilerlediğini göstermektedir. Bu bağlamda sorulması gereken soru şudur: "katılımcı öğretmenler neden salt öğrenci-öğretmen etkileşimini öne çıkaran bir ikili konuşmayı derslerde merkezileştirmişlerdir?"

Öğretmenlerin sıklıkla sınıf söylemine müdahale etmesinin diğer sebebi ise diyaloglardaki varlıklarının azalması durumunda sınıf üyelerinin sınıf içi tartışmada ele alınan konunun ekseninden ayrılma eğilimleri olarak görülebilir. Hogan, Nastasi ve Pressley (1999) öğrenci rehberliğinde ve öğretmen rehberliğinde oluşturulan etkileşimlerde tartışmaya konu olan kavramların akış içinde tutarlı bir şekilde sürdürülebilirliğini incelemişlerdir. Öğrenci rehberliğinde oluşturulan tartışmalarda öğretmen rehberliğinde oluşturulan tartışmalara kıyasla daha çok öğrencilerin tartışmaya katkı sağladığı ortaya koyulmuştur. Bunun yanı sıra öğrenci rehberliğinde oluşturulan tartışmalarda ele alınan konuda bütünlük sağlanamadığı ve söylemde yer alan fikir, iddia ya da katkıların kavramsal tutarlılık açısından parçalı halde olduğu görülmüştür. Öğretmen müdahalesinin olmadığı öğrenci rehberliğinde oluşturulan tartışmalarda öğrenciler, ön planda tutulması ya da geri planda bırakılması gereken iddia ve katkıları ayrıştırmayarak sınıf söyleminin sürdürülmesine neden olmuşlardır. Öğretmen rehberliğinde oluşturulan tartışmalarda ise öğretmenler sınıf söylemini anlamlı bir noktaya ulaştırmak için tartışılan kavramın özünü ve gerekliliklerini belirginleştirerek amaçlı bir şekilde yönlendirmişlerdir (Hogan vd., 1999).

Tablo 7'de görüldüğü üzere öğretmen müdahalesi olmadan öğrenciler kendi aralarında (Sıra 48 ile 77 arasında) konuşarak sınıf söylemine katkıda bulunmuşlardır. Öğrenciler tarafından "T(S×30): Öğretmen- Öğrenci - ... - Öğrenci (30 öğrenci diyaloğu)" şeklinde oluşturulan bu etkileşim örüntüsünde ögrretmenin (Sıra 47) yönelttiği soru ile örüntü başlamıştır ve bu soruya S15 (Sıra 48) yanıt vererek örüntüyü devam ettirmiştir. Bunun hemen ardından S16 (Sıra 49) tartışılan kavramsal içeriğin dışına çıkarak S15'e bir soru yöneltmiştir. Öğretmen müdahalesi olmadan Sıra 78'e kadar öğrenciler kendi aralarında diyalog oluşturmuşlardır. Diyaloglarının içeriği incelendiğinde sınıf söyleminde tartışılan kavramsal içeriğin dışına çıktıkları görülmektedir ve öğretmen müdahalesi öncesinde kavramsal içeriğin eksenine girememişlerdir. Öğretmenin etkileşim örüntüsündeki varlığının gerekliliği öğrencilerin kavramsal içerikten hızlıca sapmaları ile gözler önüne serilmektedir. Okul öncesi eğitimi bağlamında düşünüldüğünde öğretmenlerin iş birlikli paylaşımlı düşünme ve öğrenme ortamı yaratmak amacıyla öğrencilerle etkileşime girdiği ve bu anlayışı sürdürdükleri bilinmektedir (Frejd, 2019). Öğretmenlerin sınıf içinde paylaşılan bir iddia hakkında diğer sınıf üyelerini düşünmeye yönlendirmesi, öğrenci katkılarının diğer sınıf üyeleri tarafından tanımlanmasını ya da genișletilmesini talep etmesi iş birlikli - paylaşımlı düşünmenin sürdürülmesine işaret etmektedir. Bunun yanı sıra erken çocukluk dönemindeki çocuklar (üç ile beş yaş aralığı) yetişkinlerle girdikleri etkileşimlerde genellikle birebir diyalog (T-S-T-S) örüntüsü olușturmaktalardır (Frejd, 2019). Bu çalıșma kapsamındaki TS konuşma sırası etkileşim örüntüleri düşünüldüğünde öğretmenlerin iş birlikli - paylaşımlı düşünme ortamlarını sınıf söyleminde yaratma yöneliminde oldukları ve bunun ancak öğretmen rehberliğinde yaratılabildiği söylenebilir. Öğrencilerin sınıf içi tartışmadaki kavramsal tutarlıı̆ı tek başına sağlayamamaları nedeniyle öğretmen varlığına intiyaç duyulmaktadır. Bu gerçeğin yanı sıra öğretmen müdahalelerinin iş birlikli - paylaşımlı düşünmeye ve bu anlayışta öğrenmeye engel teşkil etmemesi göz önünde bulundurulmalıdır. Bu durum diğer çalışmalarda da tespit edilmiştir (Hamel vd., 2020; Meeks vd., 2020; Nyarambi, 2020; Wood, 2020). Sonuç olarak öğretmenin etkileșim örüntülerini başlatma, devam ettirme ve sonlandırma süreçlerinde pragmatist bir dengeyi ya da söylemsel bir harmoniyi sağlaması etkin ya da entelektüel açıdan üretken okul öncesi sınıf içi diyalogu mümkün ve sürdürülebilir kılacaktır (Bouchard vd., 2020)

Araştırma kapsamında Öğretmen Ayşe ve Öğretmen Bilge'nin birbirine yakın eğilimlerle üçlü etkileşim örüntüsü türlerini sergilediği görülmüştür. Öğretmenlerin 10 ifadesinden altısının BCT (takip sorusu yöneltme), üçünün BCA (açıklama) ve birinin ise BCD (değerlendirme) niteliği taşııdığı belirlenmiştir. Üçlü etkileşim örüntülerinin incelendiği çalışmalarda BCD ve BCA örüntüleri kullanım eğiliminin bilişsel olarak süreçlere bağlama, etkinlik türüne ve katılımcı öğrenci grubunun yaş düzeyi gibi özelliklere göre çeşitlilik gösterdiği belirlenmiştir. İki yaş ve altındaki öğrencilerle gerçekleştirilen çalışmalarda BCA örüntülerinin sıklıkla kullanıldığı, okul öncesi eğitim kapsamında hikâye okuma ve ilişkili tartışmalar oluşturmaya yönelik etkinliklerde öğretmenlerin BCD örüntülerini kullanma eğiliminde olduğu görülmüştür (Degotardi ve Han, 2020; Mascareño vd., 2017). BCA örüntülerinin tekrarlayıcı, açıklaştırıcı ve derinleştirici özellikleri düşünüldüğünde erken çocuktaki bireylerin dil gelişimini destekleyici nitelikte olduğu söylenebilir (Wood, 2020). Cullen (2002), yabancı dil ediniminde yeni bir dile uyum sağlamaya çalışan öğrencilerin ifadelerinin yapısal olarak ögretmen tarafından düzenlenmesi ve yeniden söyleme katılmasının iletişimsel bir katkı olduğunu vurgulamaktadır. BCA örüntülerinin yapısal olarak düzenlemeler sağladığı düşünüldüğünde erken çocukluk döneminde gelişmekte olan dil becerisinin desteklendiği ve dilsel açıdan ustalıkla oluşturulmuş cümle yapıları içermeyen öğrenci ifadelerinin sağlıklı bir şekilde sınıf söyleminde tekrar yapılandırıldığı söylenebilir. BCA örüntüleri hem dil becerilerini destekleyici etkisi hem de iletişimsel düzenleme sağlayan katkısı ile okul öncesi eğitimde işlevsel olarak kullanılabilir (Nyarambi, 2020: Wood, 2020). Fakat BCA örüntüleri aynı zamanda öğretmen perspektifinden sağlanan öznel ifade, iddia ve açıklamaları da içermektedir. Bu nedenle BCA ve BCD örüntülerinin kullanımı sınıf söyleminde sergilenen iletişimsel yaklaşımın otoriter ya da diyalojik olmasını doğrudan etkilemektedir (Hamel vd., 2020; Meeks vd., 2020; Mortimer ve Scott, 2003). BCT örüntüsü kullanımı da öğretmenin sınıf söylemine takip soruları ile katkı sağlayarak iletişimsel yaklaşımı belirlemesine neden olabilir. Otoriter iletişimsel yaklaşımda birbirinden farklı iddia ve ifadelerin keşfedilmesine alan sağlanmamaktadır ya da öğretmen özellikle belirlediği noktaya ulaşmak amacıyla etkileşime girmektedir. Oysaki öğretmen diyalojik iletişimsel yaklaşım ile sınıf söylemini sürdürdüğünde birbirinden farklı iddia ve ifadelere yer vardır ve öğretmen bu ifadelerin art alanını ortaya çıkarma eğilimindedir (Oosterhoff, 2020; Zhou ve Hedges, 2020). Dolayısıyla öğretmenin BCT örüntüsü kullanırken öğrenci ifadelerinin art alanını keşfetme işleviyle sorular yöneltmesi ile kavramsal akışta ulaşmak istediği noktaya gelmek üzere sorular yöneltmesi arasında iletişimsel yaklaşımın belirlendiği bir ayrım oluşmaktadır. Başka bir deyișle öğretmenin BCT örüntüsü kullanması yani takip sorusu yöneltmesi iletişimsel yaklaşımın diyalojik olduğunun tek göstergesi olamamaktadır. Belirleyici olan unsurlar yöneltilen takip sorusunun niteliği ve bağlamdaki işlevidir. $\mathrm{Bu}$ nedenle öğretmenin sınıf içi tartışmalarda sergilediği söylemsel hamle türevlerinin ve eğilimlerinin belirlenmesi öğretmenin BCD, BCA ya da BCT örüntüsü kullanım eğilimi ile açıklanamayan noktaların derinlemesine incelenmesini sağlamaktadır.

Araştırma kapsamında çalışma gerçekleştirilen öğretmenler ve öğrenciler için BCD ve BCA örüntülerinin daha az kullanımı ve BCT örüntülerine alan açılması uyum sağlamalarını gerektiren bir süreç olmuştur. Özellikle günlük rutinlerindeki etkinlik çeşitlerine benzer olmayan bir yöntemle kısa bir hikâye anlatımı ve ardından uzun bir müzakere süreci 
yürütülmüştür. Sınıf söyleminin sosyokültürel bağlamda incelenebilmesi için etkileşimli (Mortimer ve Scott, 2003) bir iletişimsel yaklaşım sürdürülmesi araştırmanın gerekliliklerinden birini oluşturmaktadır. Öğrenciler ve ögrretmenler tarafından daha önce tecrübe edilmemiş ve öğrenciler üzerindeki öğretimsel çıktıları gözlemlenmemiş bu sürecin tekrarlanarak deneyimlenmesi ve bir kültüre dönüşmesi amaçlanabilir. Guskey (2002), öğretmenin öğretimsel süreçte bir değişim yaşamasının öncül koşulunu pratiklerini değiştirmesi ve bunun sonucunda öğrencide gözlemleyeceği öğretimsel çıktılar olarak belirtmiştir. Ögrencide gözlemlenen çıktıların, öğretmenin inanç ve davranışlarını değiştirmesine büyük ölçüde etkisi olacağı ifade edilmektedir. Bu nedenle sadece bir araștırma kapsamında yürütülen etkinlik dizisi öğretmenin iletişimsel yaklaşımını ve dolayısıyla sınıf söyleminde sergilediği etkileşim örüntülerini kökten değiştireceğinin ve öğretimsel süreçlere adapte edeceğinin göstergesi olmamaktadır. BCD, $B C A$ ve $B C T$ örüntülerinin yol açtığı iletişimsel yaklaşımın işlevsel kullanılması ve kalıcılığının sağlanarak bir kültüre dönüştürülmesi için uzun süreli uygulamalar ve gözlemler ile öğretmenlerin bu yönde davranışlarının değişmesi gerekli görülmektedir.

\section{Sonuç ve Eğitimsel Öneriler}

Öğretmenlerin sınıf içi tartışmalarda sergilediği TS konuşma sırası etkileşim örüntüleri çoğunlukla "T-S-T-S" örüntü özelliği göstermesi nedeniyle öğretmen müdahalesinin sık olduğunu göstermektedir. Bu durum öğrenci - öğrenci arasında yașanan diyalogları desteklemediğinden is birlikli öğrenme ve bu yöntemle bilgi yapılandırılmasını önlemektedir. Bunun yanı sıra öğretmenlerin sınıf içi konuşmalardaki varlıklarının azalması öğrencilerin tartışılan konu ekseninden uzaklaşmalarına neden olmaktadır. Bu durumda sınıf içinde sürdürülen öğrenci merkezli anlayışın iş birlikli öğrenme ile desteklenmesi ve aynı zamanda tartışılan olguya sağlıklı bir şekilde rehberlik edilmesi için öğretmenlerin sınıf söyleminde bir denge yaratmaları gerekmektedir. Özellikle okul öncesi eğitim alanında sınıf söylemindeki öğretmen varlığının azalması sonucunda öğrencilerin tartışılan olgunun ekseninden hızlıca ayrılmaları göz önünde bulundurulduğunda iş birlikli öğrenme ve sağlıklı rehberlik arasındaki dengenin düzenli uygulanan pratiklerle gerçekleşmesi sağlanabilir. Öğretmenlerin bu pratikleri özellikle sınıf söyleminin incelenmesi için belirlenmiş araştırmalar kapsamından çıkararak günlük etkinlik rutinlerine adapte etmeleri sınıf söyleminde bu pratiklerin kalıcı olmasını sağlayabilir.

Diğer etkileşim örüntüsü türü olan üçlü etkileşim örüntülerinin kullanım eğilimi öğrenci merkezli anlayışın desteklenmesi ile ilişkilidir. BCT örüntüleri öğrenci iddia ve fikirlerine önem verilen sınıf söyleminde kullanılmaktadır ve öğrenci ifadelerinin art alanını ortaya çıkarmayı amaçlayan bir eğilimle sergilenmektedir. Bu nedenle BCT örüntü kullanımının BCD ya da BCA örüntü kullanımına göre daha öğrenci merkezli bir anlayışı temsil ettiği söylenebilir. Araştırma kapsamında öğretmenlerin BCT örüntülerini sıklıkla kullandığı fakat $B C D$ ve $B C A$ örüntülerine de yer verdiği görülmektedir. $B C D$ ve $B C A$ örüntülerinin kullanım eğilimi azaldıkça sınıf söyleminin öğrenci merkezli bir anlayışa yaklaştığı düşünülebilir. Bu sebeple öğretmenlerin değerlendirici ve açıklayıcı ifadeleri azaltması uygun görülmektedir. Tartışma kısmında değinildiği üzere öğretmenin BCT kullanımını artıırması yani öğrenci merkezli bir anlayışa yaklaşması için BCT kullanımının öğrenciler üzerindeki etkilerini görmesi inançlarının değişmesine sebep olabilir. Bu nedenle BCT kullanımı öğretmenler tarafından arttırılmalı ve sınıf söylemindeki öğrenci katkılarının bu tercih sebebiyle nasıl bir değişim gösterdiği sistematik olarak incelenmelidir. Bu etkinin öğretmen pratiklerini öğrenci merkezli bir anlayışa yakınlaştıracağı ön görülebilir. Okul öncesi eğitim alanında sınıf söylemine ilişkin yapılacak araştırmalarda öğretmenlerin BCT kullanımının öğrencilere ne türde edinimler sağladığının incelenmesi hem alana hem de öğretmenlerin sınıf içi pratiklerine değerli katkılarda bulunabilir.

\section{Kaynakça}

Bouchard, C., Sylvestre, A., \& Forget-Dubois, N. (2020). Why are boys perceived as less prosocial than girls by their early childhood educators? The role of pragmatic skills in preschool and kindergarten children. Educational Psychology, 40(10), 1-21. https://doi.org/1 $0.1080 / 01443410.2020 .1742875$

Brandvoll-Haukenes, M. (2017). Feedback and assessment in the new kindergarten teacher education in Norway. Universal Journal of Educational Research, 5(7), 12011214.

Burla, L., Knierim, B., Barth, J., Liewald, K., Duetz, M., \& Abel, T. (2008). From text to codings: intercoder reliability assessment in qualitative content analysis. Nursing Research, 57(2), 113-117. https://doi.org/10.1097/01. NNR.0000313482.33917.7d

Buty, C., \& Mortimer, E. F. (2008). Dialogic/authoritative discourse and modeling in a high school teaching sequence on optics. International Journal of Science Education, 30(12), 1635-1660. https://doi. org/10.1080/09500690701466280

Cai, L., Wu, D., Chen, X., Zhu, J., \& Li, H. (2020). The fusion of constructivism and instructivism in Chinese kindergartens: An analysis of the teaching dialogues in the engineer block building activities. Early Education and Development, 1-20. https://doi.org/10.1080/1040 9289.2020.1812936

Cazden, C. B. (2001). Classroom discourse: The language of teaching and learning. Portsmouth: Heinemann.

Chin, C. (2006). Classroom interaction in science: Teacher questioning and feedback to students' responses. International Journal of Science Education, 28(11), 13151346. https://doi.org/10.1080/09500690600621100

Chin, C. (2007). Teacher questioning in science classrooms: Approaches that stimulate productive thinking Journal of Research in Science Teaching, 44(6), 815843. https://doi.org/10.1002/tea.20171

Creswell, J. W. (2012). Educational research: Planning, conducting, and evaluating quantitative and qualitative research. Boston: Pearson.

Creswell, J. W., Hanson, W. E., Clark Plano, V. L., \& Morales, A. (2007). Qualitative research designs: Selection and implementation. The Counseling Psychologist, 35(2), 236-264. https://doi.org/10.1177/0011000006287390

Cullen, R. (2002). Supportive teacher talk: The Importance of the F-move. ELT Journal, 56(2), 117-27. https://doi. org/10.1093/elt/56.2.117

Degotardi, S., \& Han, F. (2020). Quality of educatorinfant conversational interactions among infants 
experiencing varying quantity of linguistic input. European Early Childhood Education Research Journal, 28(5), 743-757. https://doi.org/10.1080/1350 $293 \times .2020 .1817245$

Denzin, N. K., \& Lincoln, Y. S. (2008). Strategies of qualitative inquiry (Vol. 2). Sage.

Edwards, D., \& Mercer, N. (1987). Common knowledge: The development of understanding in the classroom. London, UK: Methuen.

Frejd, J. (2019). When children do science: Collaborative interactions in preschoolers' discussions about animal diversity. Research in Science Education, 1-22. https:// doi.org/10.1007/s11165-019-9822-3

Gäreskog, P., \& Lindqvist, G. (2020). Working from a distance? A study of Special Educational Needs Coordinators in Swedish preschools. Nordic Studies in Education, 40(1), 55-78. https://doi.org/10.23865/nse.v40.2128

Goulding, C. (1999). Grounded theory: Some reflections on paradigm, procedures and misconceptions. Working paper series, Report no. WPo06/99, Wolverhampton: University of Wolverhampton. https://wlv. openrepository.com/handle/2436/11403 adresinden erişilmiştir.

Guskey, T. R. (2002). Professional development and teacher change. Teachers and Teaching: Theory and Practice, 8(3), 381-391. https://doi. org/10.1080/135406002100000512

Hamel, E., Joo, Y., Hong, S. Y., \& Burton, A. (2020). Teacher questioning practices in early childhood science activities. Early Childhood Education Journal, 1-10. https://doi.org/10.1007/s10643-020-01075-Z

Hogan, K., Nastasi, B. K., \& Pressley, M. (1999). Discourse patterns and collaborative scientific reasoning in peer and teacher-guided discussions. Cognition and Instruction, 17(4), 379-432.

Hu, B. Y., Li, Y., Zhang, X., Roberts, S. K., \& Vitiello, G. (2021). The quality of teacher feedback matters: Examining Chinese teachers' use of feedback strategies in preschool math lessons. Teaching and Teacher Education, 98. https://doi.org/10.1016/j. tate.2020.103253

Leach, J., \& Scott, P. (2002). Designing and evaluating science teaching sequences: An approach drawing upon the concept of learning demand and a social constructivist perspective on learning. Studies in Science Education, 38, 115-142. https://doi. org/10.1080/03057260208560189

Lemke, J. L. (1990). Talking science: Language, learning and values. Norwoord, NJ: Ablex.

Mascareño, M., Deunk, M. I., Snow, C. E., \& Bosker, R. J. (2017). Read-alouds in kindergarten classrooms: A momentby-moment approach to analyzing teacher-child interactions. European Early Childhood Education Research Journal, 25(1), 136-152. https://doi.org/10.10 80/1350293X.2016.1266226

Matengu, M., Ylitapio-Mäntylä, O., \& Puroila, A. M. (2020). Early childhood teacher education practicums: A literature review. Scandinavian Journal of Educational Research 1-15. https://doi.org/10.1080/00313831.2020.1833245.

Meeks, L., Madelaine, A., \& Stephenson, J. (2020). New teachers talk about their preparation to teach early literacy. Australian Journal of Learning Difficulties, 1-21. https://doi.org/10.1080/19404158.2020.1792520

Mehan, H. (1979). Learning lessons. Cambridge, MA: Harvard University Press.

Mercer, N. (2004). Sociocultural discourse analysis: Analysing classroom talk as a social mode of thinking. Journal of Applied Linguistic, 1(2), 137-168.

Mercer, N. (2010). The analysis of classroom talk: Methods and methodologies. British Journal of Educational Psychology, 80(1), 1-14. https://doi. org/10.1348/000709909X479853

Merriam, S. B. (1998). Qualitative research and case study applications in education: Revised and expanded from case study research in education. San Francisco: Jossey-Bass.

Milli Eğitim Bakanlığı. (2013). Okul öncesi eğitim programı. Ankara.

Mortimer, E. F., \& Scott, P. H. (2003). Meaning making in secondary science classrooms. Maidenhead, England: Open University Press.

Muhonen, H., Verma, P., von Suchodoletz, A., \& RaskuPuttonen, H. (2020). Exploring types of educational classroom talk in early childhood education centres. Research Papers in Education, 1-22. https://doi.org/10 $.1080 / 02671522.2020 .1784259$.

Nassaji, H., \& Wells, G. (2000). What's the use of 'triadic dialogue'? An investigation of teacher-student interaction. Applied Linguistics, 21(3), 376-406.

Nyarambi, A., \& Ntuli, E. (2020). A study of early childhood development teachers' experiences in Zimbabwe: Implications to early intervention and special education. Open Journal for Educational Research, 4(1), 49-66.

Oosterhoff, A. M., Oenema-Mostert, I. C., \& Minnaert, A. E. (2020). Aiming for agency. The effects of teacher education on the development of the expertise of early childhood teachers. Teaching and Teacher Education, 96. https://doi.org/10.1016/j.tate.2020.103176

Piaget, J. (2015). Çocuğun ahlaki yargısı. (Çev. i. Dündar). İstanbul: Pinhan. (Orijinal eserin yayın tarihi 1932).

Scott, P. (1998). Teacher talk and meaning making in science classrooms: A Vygotskian analysis and review. Studies in Science Education, 32, 45-80.

Scott, P. H., Mortimer, E. F., \& Aguiar, O. G. (2006). The tension between authoritative and dialogic discourse: A fundamental characteristic of meaning making interactions in high school science lessons. Science Education, 90(4), 605-631. https://doi.org/10.1002/ sce.20131

Sinclair, J. McH., \& Coulthard, R. M. (1975). Towards an analysis of discourse: The English used by teachers and pupils. 
London: Oxford University Press.

Soysal, Y. (2018a). Determining the mechanics of classroom discourse in vygotskian sense: Teacher discursive moves reconsidered. Research in Science Education, 50, 1639-1663. https://doi.org/10.1007/s11165-0189747-2

Soysal, Y. (2018b). A review of the assessment tools for the student-led cognitive outcomes/contributions in the sense of inquiry-based teaching. Elementary Education Online, 17(3), 1476-1495. https://doi. org/10.17051/ilkonline.2018.466372

Soysal, Y. (2019a). Investigating discursive functions and potential cognitive demands of teacher questioning in the science classroom. Learning: Research and Practice, 6(2), 167-194. https://doi.org/10.1080/23735 082.2019 .1575458

Soysal, Y. (2019b). Fen öğretiminde öğretmenin söylemsel hamlelerinin öğrenenlerin akıl yürütme kalitelerine etkisi: Söylem analizi yaklaşımı. Research in Education, 7(3), 994-1032.

Soysal, Y. (2019c). Indicators of productive classroom talk and supporting discourse moves: A systematic review for effective science teaching. Academy Journal of Educational Sciences, 3(2), 114-137. https://doi. org/10.31805/acjes.642246

Soysal, Y. (2019d). Meaning and formats of classroom discourse in the context of teacher discursive moves. Elementary Education Online, 18(2), 600-620. https:// doi.org/10.17051/ilkonline.2019.562025

Soysal, Y. (2020a). Investigating the discursive interactions in the elementary science classroom. Elementary Education Online, 19(1), 1-17. https://doi.org/10.17051/ ilkonline.2020.641896

Soysal, Y. (2020b). Establishing the norms of the Vygotskian teaching in the science classroom. Elementary Education Online, 19(3), 1838-1857. 1 https://doi. org/0.17051/ilkonline.2020.735202

Soysal, Y., \& Radmard, S. (2020). Research into teacher educators' discursive moves: A Vygotskian perspective. Journal of Education, 200(1), 32-47. https://doi.org/10.1177/0022057419875120

Soysal, Y., \& Yilmaz-Tuzun, O. (2019). Relationships between teacher discursive moves and middle school students' cognitive contributions to science concepts. Research in Science Education, 1-43. https://doi.org/10.1007/ s11165-019-09881-1

Wells, G. (1999). Dialogic inquiry: Towards a sociocultural practice and theory of education. New York, NY: Cambridge University Press.

Wells, G. (Ed.) (2001). Action, talk, and text: Learning and teaching through inquiry. New York, NY: Teachers College Press

Wood, E. (Ed.). (2020). The Routledge reader in early childhood education. Routledge.

Zhou, D., \& Hedges, H. (2020). Multiple intelligences theory in Chinese kindergartens: Influences on teacher implementation. International Journal of Early Years Education, 1-14. https://doi.org/10.1080/09669760.2 020.1814219 . 